Nevada

Environmental

Restoration

Project

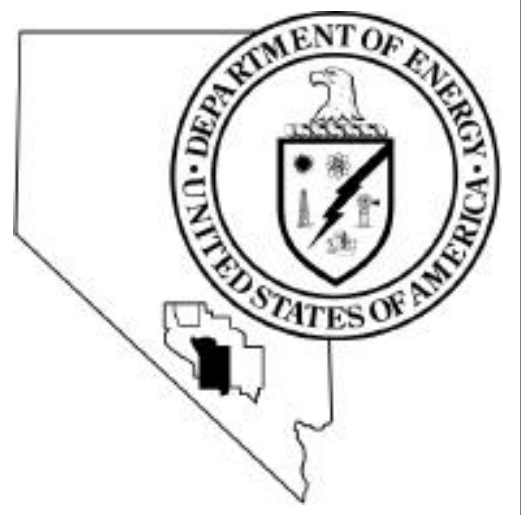

Housekeeping Closure Report for

Corrective Action Unit 119:

Storage Tanks, Nevada Test Site,

N evada

Controlled Copy N $0 .:$

Revision $\mathrm{N}_{0 .:} \mathrm{O}$

J une 2000

Approved for public release; further dissemination unlimited.

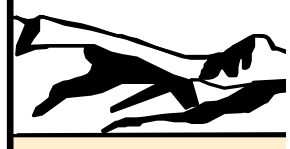

Environm ental Restoration

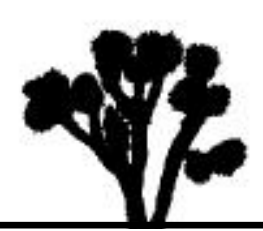

Division 
Available for sale to the public, in paper, from:

\author{
U.S. Department of Commerce \\ National Technical Information Service \\ 5285 Port Royal Road \\ Springfield, VA 22161 \\ Phone: 800.553 .6847 \\ Fax: 703.605.6900 \\ Email: orders@ntis.fedworld.gov \\ Online ordering: http//www.ntis.gov/ordering.htm
}

Available electronically at http://www.doe.gov/bridge.

Available for a processing fee to U.S. Department of Energy and its contractors, in paper, from:

\author{
U.S. Department of Energy \\ Office of Scientific and Technical Information \\ P.O. Box 62 \\ Oak Ridge, TN 37831-0062 \\ Phone: 865.576.8401 \\ Fax: 865.576.5728 \\ Email: reports@adonis.osti.gov
}

Reference herein to any specific commercial product, process, or service by trade name, trademark, manufacturer, or otherwise, does not necessarily constitute or imply its endorsement, recommendation, or favoring by the United States Government or any agency thereof or its contractors or subcontractors. 


\title{
HOUSEKEEPING CLOSURE REPORT FOR CORRECTIVE ACTION UNIT 119: STORAGE TANKS, NEVADA TEST SITE, NEVADA
}

\author{
DOE Nevada Operations Office \\ Las Vegas, Nevada
}

Controlled Copy No.:

Revision No.: 0

June 2000

Approved for public release; further dissemination unlimited. 


\section{HOUSEKEEPING CLOSURE REPORT FOR CORRECTIVE ACTION UNIT 119: STORAGE TANKS, NEVADA TEST SITE, NEVADA}

Approved by: $\frac{\text { Signature Approved }}{\text { Janet Appenzeller-Wing, Project Manager }} \begin{aligned} & \text { Industrial Sites Project } \\ & \text { Inte: 6/26/2000 }\end{aligned}$

Approved by: $\frac{\text { Signature Approved }}{\begin{array}{l}\text { Runore C. Wycoff, Division Director } \\ \text { Environmental Restoration Division }\end{array}}$ Date: $\frac{6 / 26 / 2000}{\text {. }}$




\section{FFACO CORRECTIVE ACTION UNIT Closure Report SuMmary}

FACILITy NAME: NevadA TeSt Site

CORRECTIVE ACTION UnIT NUMBER: 119

Sites: AbOVEGROUnd StORAGE TANKS AND UndERgROUND StORAGE TANKS

$\begin{array}{ll}\text { CORRECTIVE ACTION SITE NUMBERS: } & 01-01-01 \\ 02-01-01 \\ 02-02-02 \\ 03-01-02 \\ 04-01-01 \\ 04-01-02 \\ 07-01-01 \\ 07-01-02 \\ 07-99-04 \\ 07-99-05 \\ 08-01-02 \\ 08-01-03 \\ 18-02-01 \\ 18-02-02 \\ 25-01-09 \\ 25-01-11 \\ 25-01-14 \\ 25-23-14 \\ 26-02-03\end{array}$




\section{FFACO Corrective ACTION Site Housekeeping Closure Verification Form}

CAU 119 Housekeeping Closure Report

Revision: 0

Date: $06 / 27 / 2000$

Page 2 of 20

Closure Verification Date: February 4, 1997

CAS Number: 01-01-01

CAU Number: 119

General Location: Area 1 Batch Plant

Elevation: 1,344 meters (m)

Latitude: 37.060969

Longitude: -116.128848

Northing: 6256529

Easting: 547829

Coordinate/Elevation Data Obtained from NORTH AMERICAN DATUM, 1927.

Site Access Route: Proceed north on Mercury Highway to Tippipah Highway, turn left (northwest). Proceed to the intersection of Tippipah Highway and Pahute Mesa Road. The Batch Plant is on the northwest corner of the intersection. The tank was located on the southwest corner of the Batch Plant.

\begin{tabular}{|l|l|}
\hline \multicolumn{1}{|c|}{ Waste Item(s) Originally at Site } & \multicolumn{1}{c|}{ Apparent Waste Type* } \\
\hline Aboveground Storage Tank (AST) & Unknown \\
\hline
\end{tabular}

* Ordinary, Scrap Metal, Asbestos, Polychlorinated Biphenyls (PCBs), Salvageable, Hazardous, Radioactive, Mixed, Unknown, Other

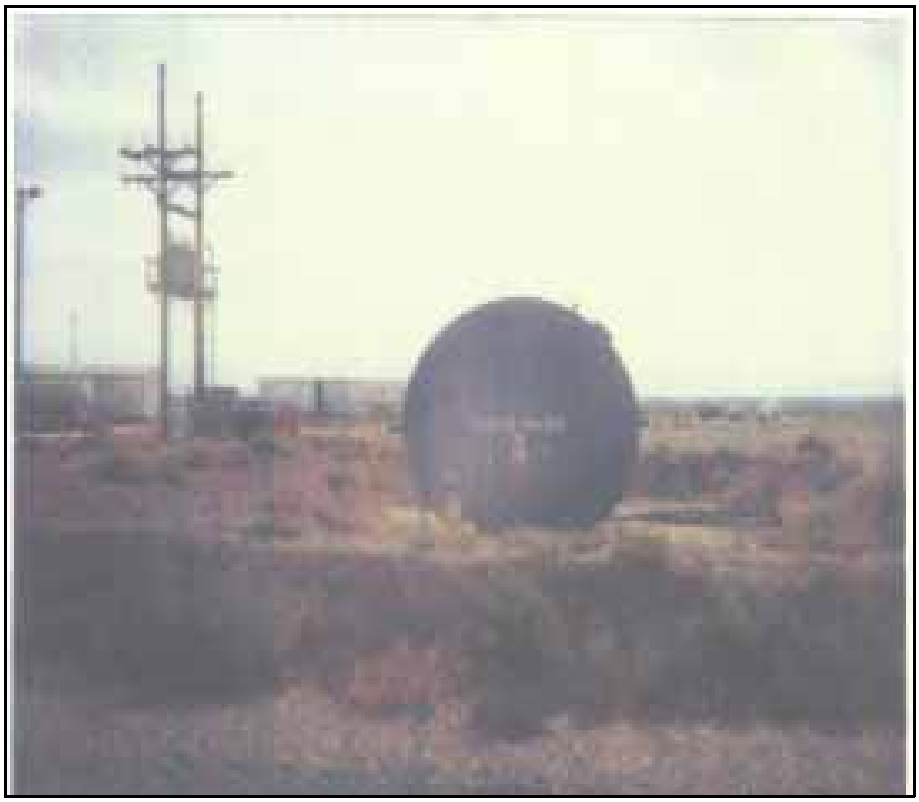

CAS Prior to Cleanup

Photograph date: 01/17/1991

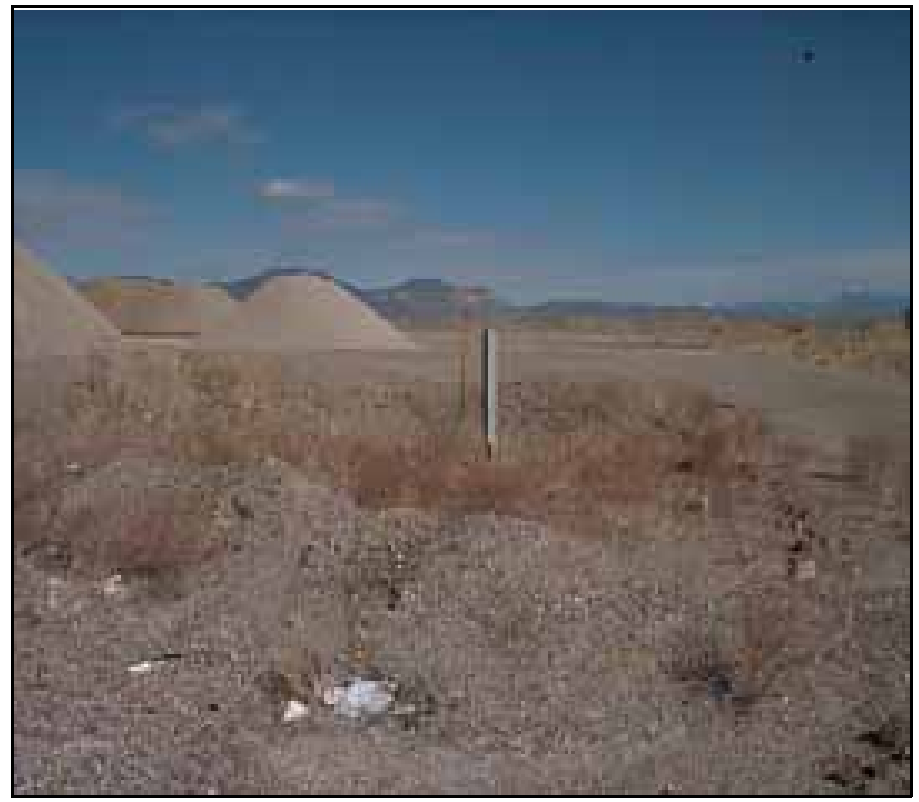

CAS After Cleanup

Photograph date: 02/04/1997

Current Site Description/Observations: The site was originally identified by an IT Corporation, Las Vegas (ITLV) field crew on May 26, 1993, as an AST-labeled waste water and oil. Reynolds Electrical \& Engineering Co., Inc. (REECo) had taken a photograph of Corrective Action Site (CAS) 01-24-01 on January 17, 1991, which also captured CAS 01-01-01, AST. The site was revisited by an ITLV field crew on February 4, 1997, and it was determined that the AST had been removed. There was no staining identified in the area where the tank was located.

\section{No Further Action Required at Corrective Action Site}

Brad Jackson (Industrial Sites Project Manager)

Signature Approved, 29 June 2000

Corrective Action Coordinator/Designee

(Signature)

Date 


\section{FFACO CORRECTIVE ACTION SITE HOUSEKEEPING Closure VERIFICATION FORM}

Closure Verification Date: July 13, 1998

CAS Number: 02-01-01

General Location: U-2gh Post-shot Area

Latitude: 37.112940000

Longitude: -116.053370000
CAU 119 Housekeeping

Closure Report

Revision: 0

Date: 06/27/2000

Page 3 of 20

Coordinate/Elevation Data Obtained from NORTH AMERICAN DATUM, 1927.

Site Access Route: Proceed north on Mercury Highway to Rainier Mesa Road, turn left (northwest). Continue to 9-01 Road, turn right (east) and proceed 1.3 miles to Circle Road. Turn right (south) on Circle Road and proceed approximately 1.4 miles to Metropolis Trailer Pad, turn right (west). Follow the road straight to the U-2gh post-shot area. The site is located $60 \mathrm{feet}$ (ft) west of the U2gh crater fence.

\begin{tabular}{|l|l|}
\hline \multicolumn{1}{|c|}{ Waste Item(s) Originally at Site } & Apparent Waste Type* \\
\hline Eight Gas Sampling Tanks & Other \\
\hline
\end{tabular}

* Ordinary, Scrap Metal, Asbestos, PCBs, Salvageable, Hazardous, Radioactive, Mixed, Unknown, Other

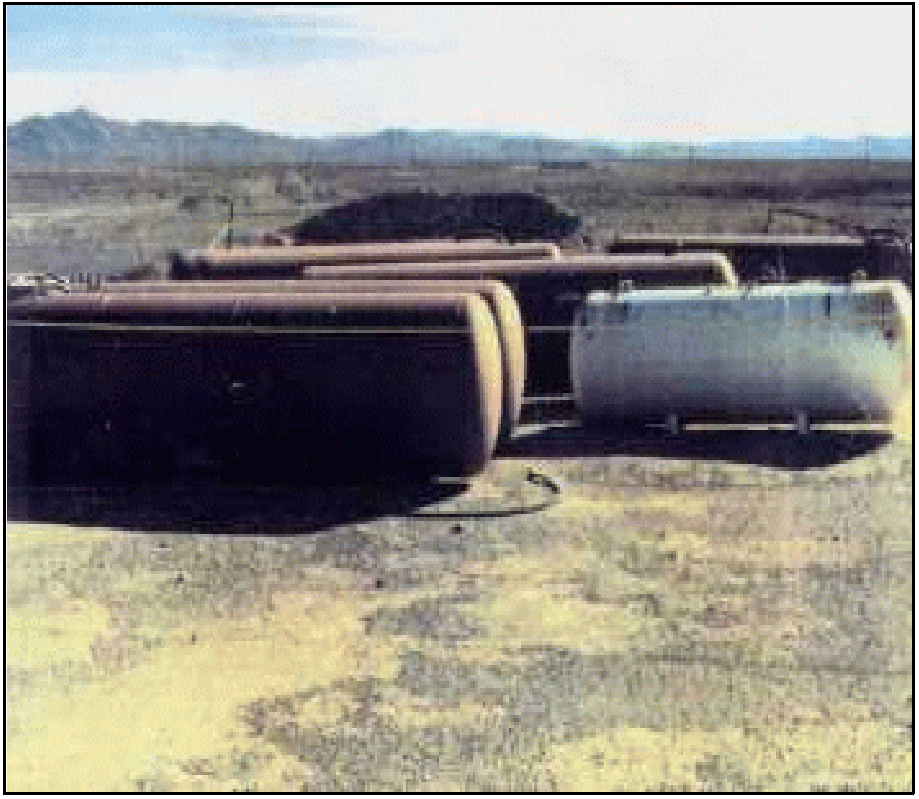

CAS Prior to Cleanup

Photograph date: 01/24/1991

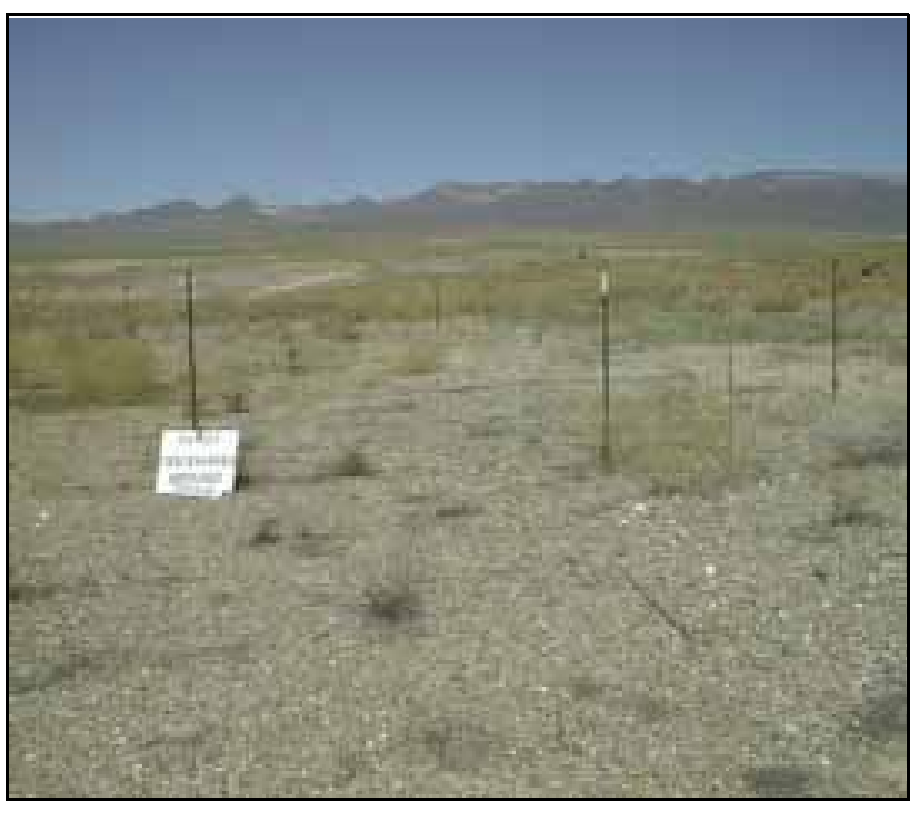

CAS After Cleanup

Photograph date: 07/15/1998

Current Site Description/Observations: The site was

originally identified by REECo on January 24, 1991, as eight aboveground gas sampling tanks. Documentation dated May 14, 1992, states that these ASTs were removed by Lawrence Livermore National Laboratory (LLNL). An ITLV field crew visited the site on July 13, 1998, and confirmed that the tanks were no longer present. A crew returned on July 15, 1998, to photograph the site.

\section{No Further Action Required at Corrective Action Site}

Brad Jackson (Industrial Sites Project Manager)

Signature Approved, 29 June 2000 


\section{FFACO CORRECTIVE ACTION SITE HouseKeEPING Closure VERIFICATION FoRM}

Closure Verification Date: June 9, 1993

CAS Number: $02-02-02$

General Location: U-2cu Post-shot \#1A

Latitude: 37.1275503

Longitude: -116.1231459
CAU 119 Housekeeping

Closure Report

Revision: 0

Date: $06 / 27 / 2000$

Page 4 of 20

\section{Coordinate/Elevation Data Obtained from NORTH AMERICAN DATUM, 1927.}

Site Access Route: Proceed north on Mercury Highway to Rainier Mesa Road, turn left (northwest). Proceed to 2-04 Road, turn left (west) onto 2-04 Road and proceed approximately 1.5 miles to the dirt road located at a 4-way intersection. Turn left (south) onto the dirt road and proceed approximately 1.0 mile to the U-2cu post-shot \#1A area. The site is on a ridge to the west of the crater.

\begin{tabular}{|l|l|}
\hline \multicolumn{1}{|c|}{ Waste Item(s) Originally at Site } & Apparent Waste Type* \\
\hline Underground Storage Tank (UST) & Unknown \\
\hline
\end{tabular}

* Ordinary, Scrap Metal, Asbestos, PCBs, Salvageable, Hazardous, Radioactive, Mixed, Unknown, Other

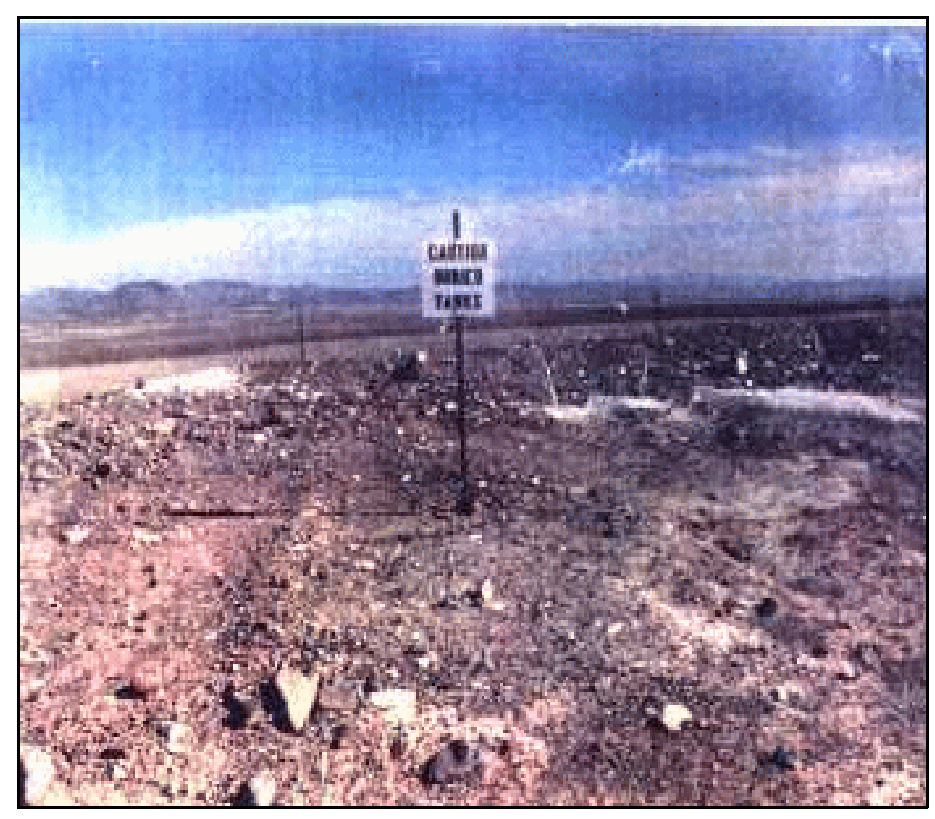

CAS Prior to Cleanup

Photograph date: 10/19/1990

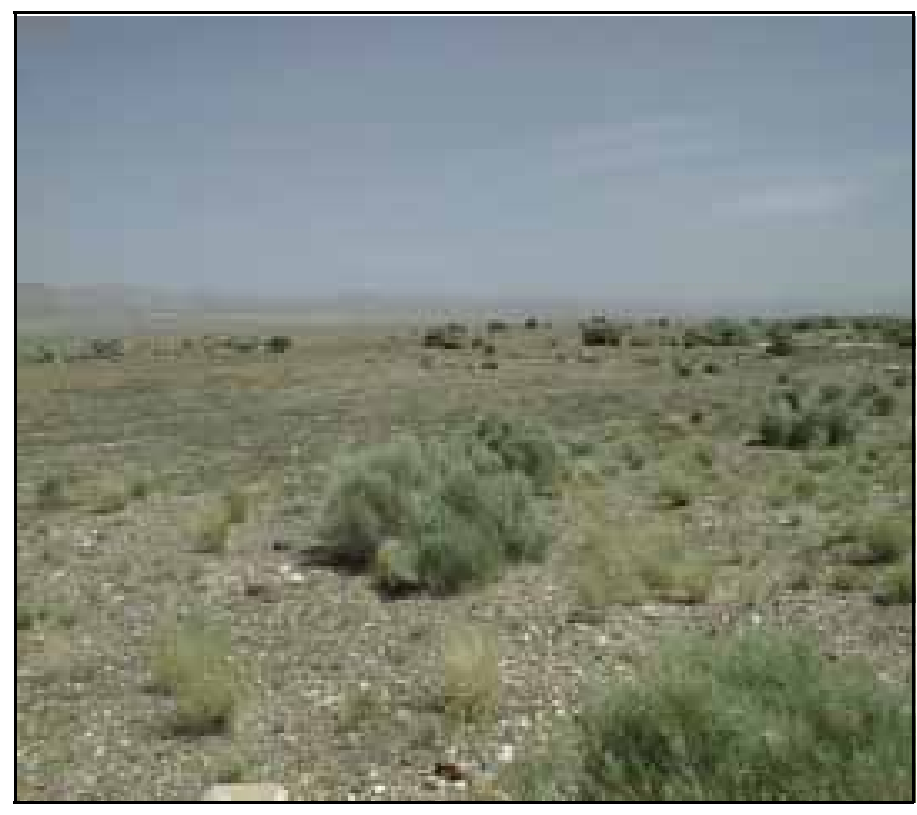

CAS After Cleanup

Photograph date: 05/10/2000

Current Site Description/Observations: The site was originally identified by REECo on October 19, 1990, as buried tanks. Documentation dated May 14, 1992, states that these USTs were removed by LLNL. An ITLV field crew visited the site on June 9, 1993, and noted soil disturbance in the area where the USTs had formerly been located. An ITLV field crew returned on May 10, 2000, to photograph the site to match the original REECo photograph. They noted that there were no "Caution Buried Tanks" signs anywhere in the surrounding area.

No Further Action Required at Corrective Action Site

Brad Jackson (Industrial Sites Project Manager)

Signature Approved, 29 June 2000

Corrective Action Coordinator/Designee

(Signature)

Date 


\section{FFACO CORRECTIVE ACTION Site HouseKeEPING Closure Verification ForM}

CAU 119 Housekeeping Closure Report

Revision: 0

Date: $06 / 27 / 2000$

Page 5 of 20

Closure Verification Date: July 13, 1998

CAS Number: 03-01-02

CAU Number: 119

General Location: U-3ev-3 Shaft

Elevation: $1,219 \mathrm{~m}$

Latitude: 37.051493333

Northing: 4100861

Longitude: -115.987355000

Easting: 590044

Coordinate/Elevation Data Obtained from NORTH AMERICAN DATUM, 1927.

Site Access Route: Proceed north on Mercury Highway to 3-03 Road, turn right (east). Proceed 3.5 miles on 3-03 Road to U-3ev-3 Shaft. The site is $600 \mathrm{ft}$ southeast of the shaft.

\begin{tabular}{|l|l|}
\hline \multicolumn{1}{|c|}{ Waste Item(s) Originally at Site } & \multicolumn{1}{c|}{ Apparent Waste Type* } \\
\hline AST & Unknown \\
\hline
\end{tabular}

* Ordinary, Scrap Metal, Asbestos, PCBs, Salvageable, Hazardous, Radioactive, Mixed, Unknown, Other

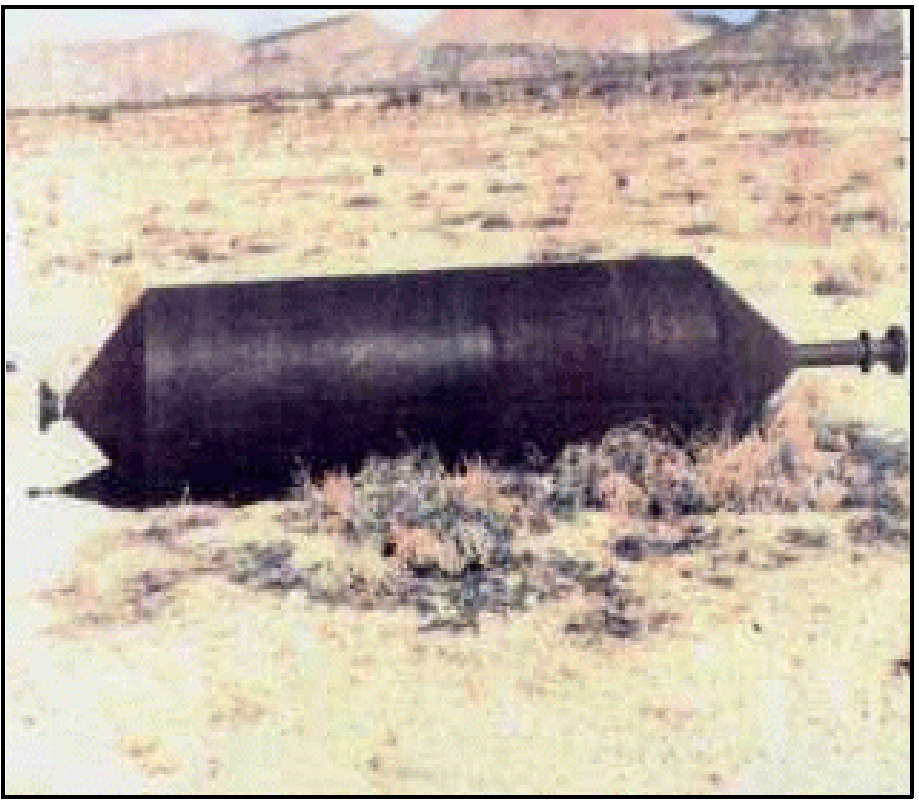

CAS Prior to Cleanup

Photograph date: 11/02/1990

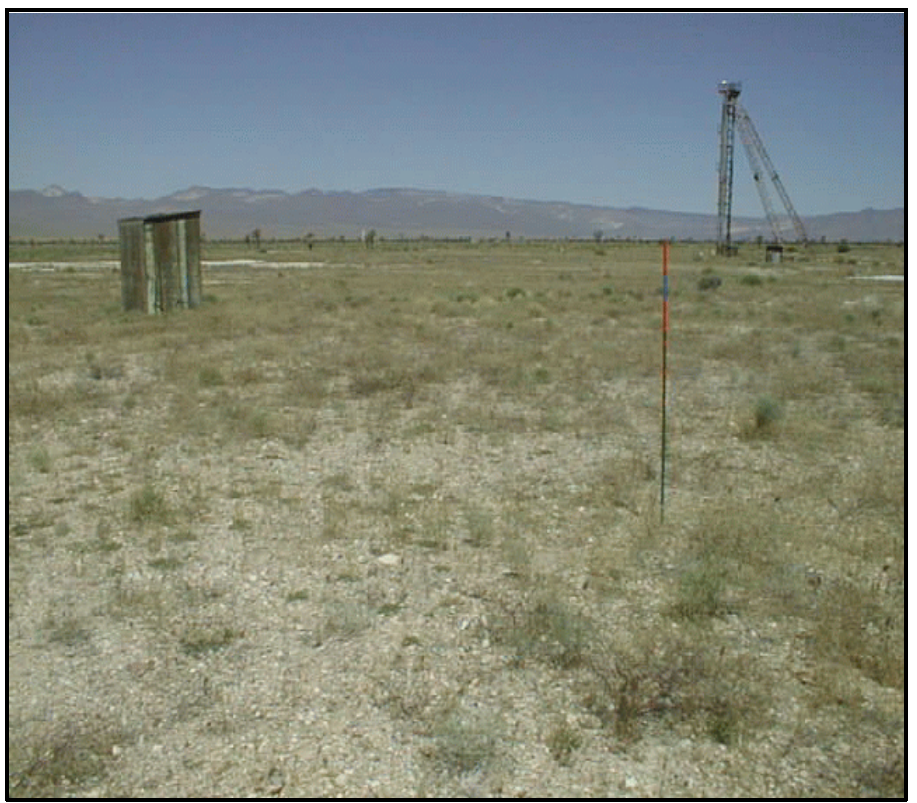

CAS After Cleanup

Photograph date: 07/15/1998

Current Site Description/Observations: The site was originally identified by REECo on November 2, 1990, as a gas sampling tank. Documentation dated May 14, 1992, states that this AST was scheduled to be removed by LLNL. An ITLV field crew visited the site on July 13, 1998, and confirmed that the tank had been removed. A crew returned on July 15, 1998, to photograph the site.

T No Further Action Required at Corrective Action Site

Brad Jackson (Industrial Sites Project Manager)

Corrective Action Coordinator/Designee
Signature Approved, 29 June 2000 (Signature) Date 


\section{FFACO Corrective ACTION Site HouseKeEPING Closure Verification Form}

CAU 119 Housekeeping Closure Report

Revision: 0

Date: $06 / 27 / 2000$

Page 6 of 20

Closure Verification Date: July 14, 1998

CAS Number: 04-01-01

CAU Number: 119

General Location: U-4ac

Elevation: $1,247 \mathrm{~m}$

Latitude: 37.092815000

Northing: 4105350

Longitude: -116.092628333

Easting: 580639

Coordinate/Elevation Data Obtained from NORTH AMERICAN DATUM, 1927.

Site Access Route: Proceed north on Mercury Highway to 4-04 Road, turn left (west). Proceed 1.6 miles to the Radiation Safety Marker (RSM) 4A-6 sign. Proceed 0.1 mile (west) beyond the sign to a dirt road on the left (south) before the bunker. Turn left (south) and proceed to the borrow pit. Drive around the borrow pit and proceed to the east side of the U-4ac crater fenceline.

\begin{tabular}{|l|l|}
\hline \multicolumn{1}{|c|}{ Waste Item(s) Originally at Site } & Apparent Waste Type* \\
\hline ASTs (3) & Other \\
\hline
\end{tabular}

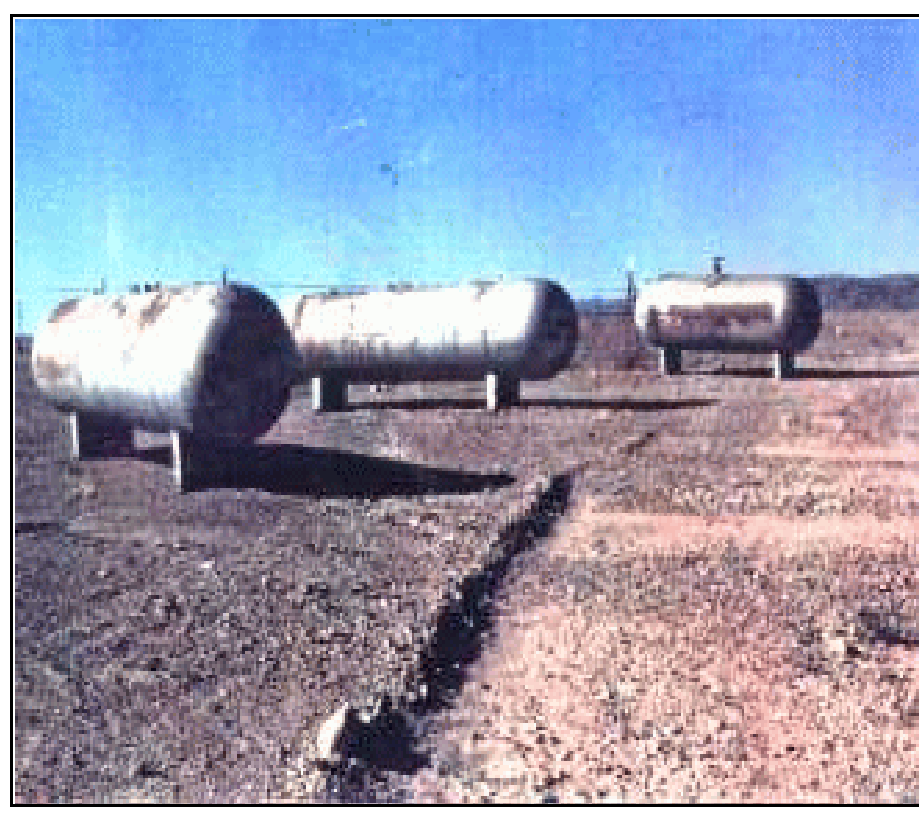

CAS Prior to Cleanup

Photograph date: 09/18/1990

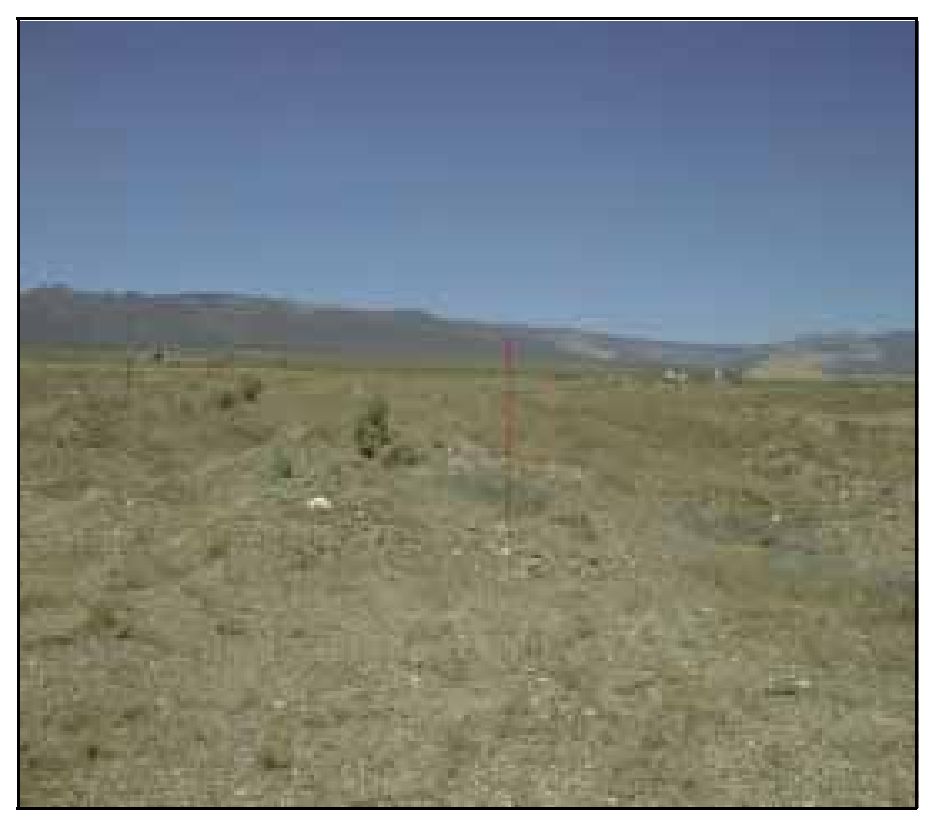

CAS After Cleanup

Photograph date: 07/14/1998

* Ordinary, Scrap Metal, Asbestos, PCBs, Salvageable, Hazardous, Radioactive, Mixed, Unknown, Other

Current Site Description/Observations: The site was originally identified by REECo on September 18, 1990, as three gas sampling tanks. Documentation dated May 14, 1992, states that these ASTs were removed by LLNL. An ITLV field crew visited the site on July 14, 1998, and confirmed that the tanks were no longer present.

\section{No Further Action Required at Corrective Action Site}

Brad Jackson (Industrial Sites Project Manager)

Corrective Action Coordinator/Designee
Signature Approved, 29 June 2000 (Signature) 


\section{FFACO CORRECTIVE ACTION Site HousekeEPING Closure VERIFICATION ForM}

CAU 119 Housekeeping Closure Report

Revision: 0

Date: $06 / 27 / 2000$

Page 7 of 20

Closure Verification Date: July 14, 1998

CAS Number: 04-01-02

General Location: U-4at Post-shot \#1

CAU Number: 119

Latitude: 37.106843333

Elevation: $1,458 \mathrm{~m}$

Longitude: -116.122526667

Northing: 4106882

Easting: 577967

Coordinate/Elevation Data Obtained from NORTH AMERICAN DATUM, 1927.

Site Access Route: Proceed north on Mercury Highway to Rainier Mesa Road, turn left (northwest). Continue just past RSM M-128 and turn left (west) onto 4-04 Road. Continue to the intersection with Orange Road, and turn right (north). Proceed 0.8 mile to a sign for U-4at, turn left (west) onto the dirt road and continue 0.25 mile to U-4at cellar.

\begin{tabular}{|l|l|}
\hline \multicolumn{1}{|c|}{ Waste Item(s) Originally at Site } & \multicolumn{1}{c|}{ Apparent Waste Type* $^{*}$} \\
\hline Gas Sampling Tank & Other \\
\hline
\end{tabular}

* Ordinary, Scrap Metal, Asbestos, PCBs, Salvageable, Hazardous, Radioactive, Mixed, Unknown, Other

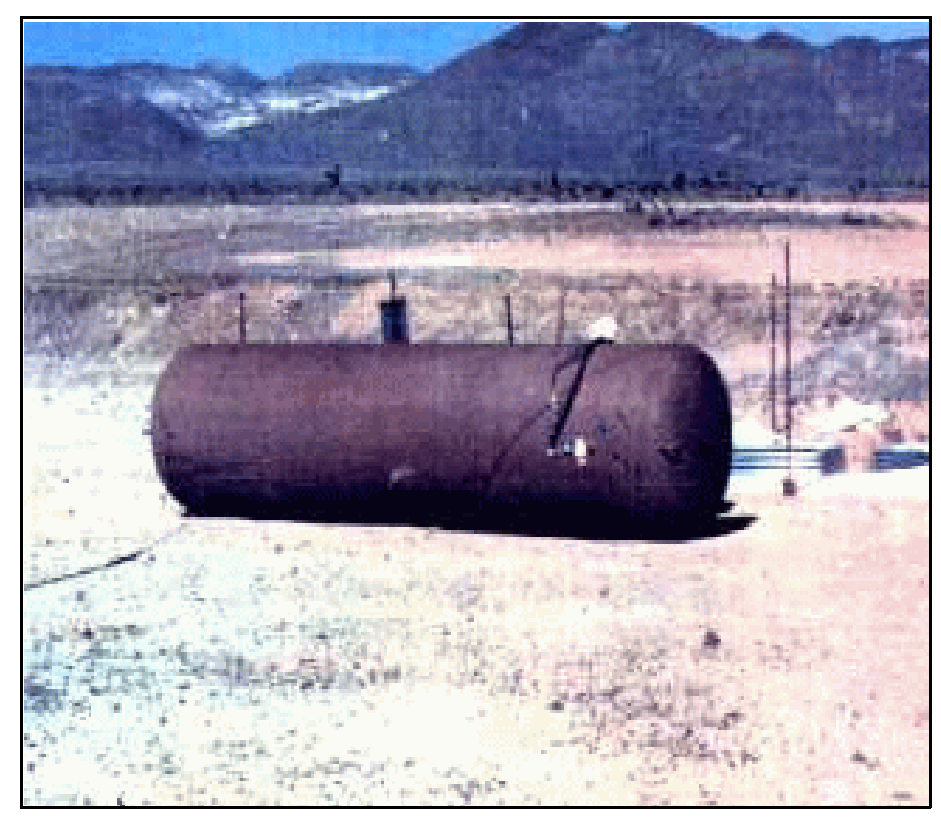

CAS Prior to Cleanup

Photograph date: 10/08/1990

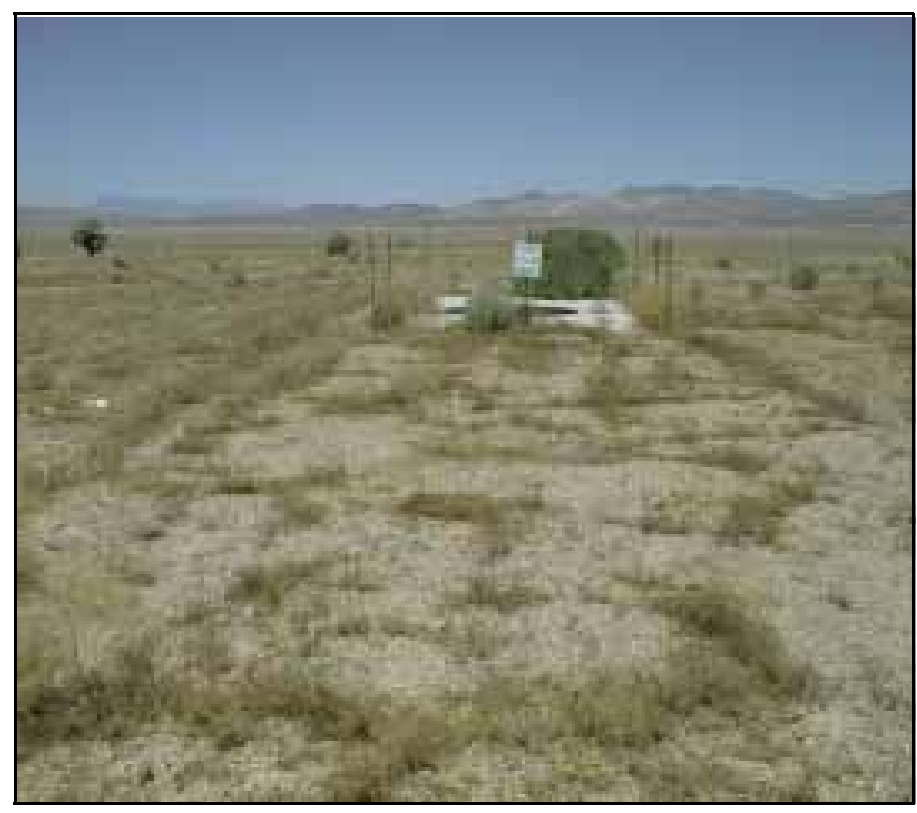

CAS After Cleanup

Photograph date: 07/14/1998

Current Site Description/Observations: The site was originally identified by REECo on October 8, 1990, as an AST used for gas sampling. Documentation dated May 14, 1992, states that this AST was removed by LLNL. An ITLV field crew visited the site on July 14, 1998, and confirmed that the tank was no longer present.

$\checkmark \quad$ No Further Action Required at Corrective Action Site

Brad Jackson (Industrial Sites Project Manager)

Signature Approved, 29 June 2000 


\section{FFACO CORRECTIVE ACTION Site HoUSEKEEPING Closure VERIFICATION FORM}

Closure Verification Date: July 14, 1998

CAS Number: 07-01-01

General Location: Bunker 7-801

Latitude: 37.090750000

Longitude: -116.032705000
CAU 119 Housekeeping

Closure Report

Revision: 0

Date: $06 / 27 / 2000$

Page 8 of 20

Coordinate/Elevation Data Obtained from NORTH AMERICAN DATUM, 1927.

Site Access Route: Proceed north on Mercury Highway to 3-03 Road, turn right (east). Proceed approximately 1.2 miles to 3-05 Road, turn left (north). Proceed approximately 2.0 miles to a fork in the road, turn left (northwest). Proceed 1.0 mile as it curves north and then approximately 0.15 mile as it curves west. Bunker 7-801 is located on the north side of the road (approximately $300 \mathrm{ft}$ ) from the road.

\begin{tabular}{|l|l|}
\hline \multicolumn{1}{|c|}{ Waste Item(s) Originally at Site } & \multicolumn{1}{c|}{ Apparent Waste Type* $^{\text {Apt }}$} \\
\hline AST & Unknown \\
\hline
\end{tabular}

* Ordinary, Scrap Metal, Asbestos, PCBs, Salvageable, Hazardous, Radioactive, Mixed, Unknown, Other

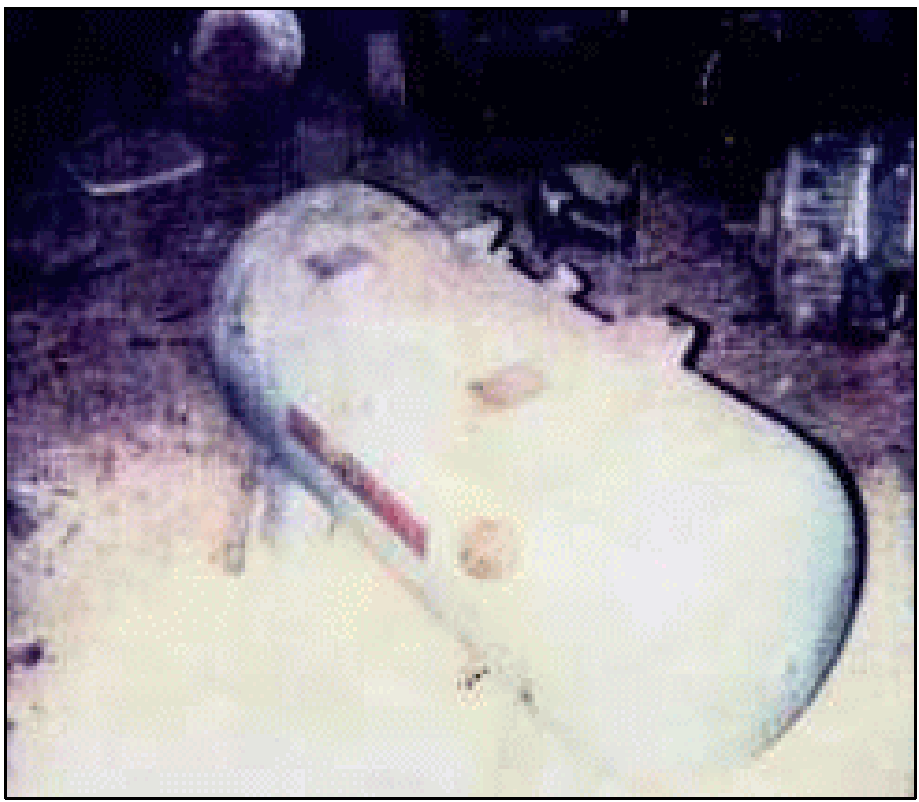

CAS Prior to Cleanup

Photograph date: 12/13/1990

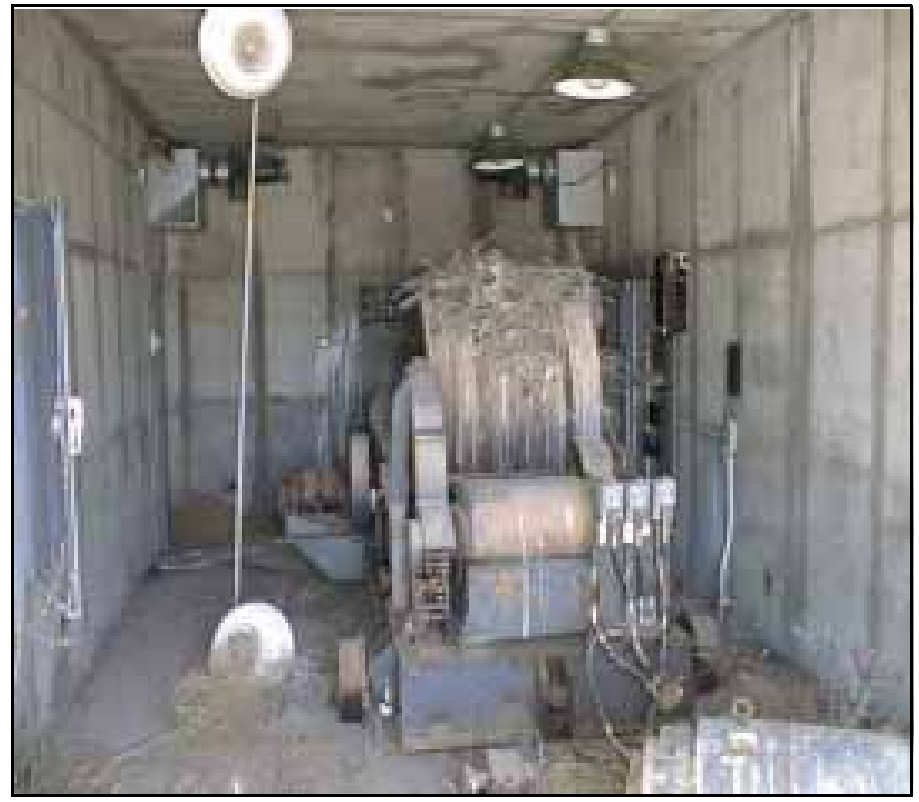

CAS After Cleanup

Photograph date: 07/14/1998

Current Site Description/Observations: The site was originally identified by REECo on December 13, 1990, as an AST located inside of Bunker 7-801. It was stated that since it was a cable pull bunker, it was probably a fuel tank. Documentation dated May 14, 1992, states that this CAS was a pressure tank that was removed by LLNL on July 30, 1991. An ITLV field crew visited the site on July 14, 1998, and confirmed that the tank was no longer present. There was no evidence of staining in the area where the tank was formerly located.

\section{$\checkmark \quad$ No Further Action Required at Corrective Action Site}




\section{FFACO Corrective ACTION Site HouseKeEPING Closure Verification Form}

Closure Verification Date: July 15, 1998

CAS Number: 07-01-02

General Location: U-7ca Crater

Latitude: 37.077433333

Longitude: -116.002266667
CAU 119 Housekeeping

Closure Report

Revision: 0

Date: 06/27/2000

Page 9 of 20

Coordinate/Elevation Data Obtained from NORTH AMERICAN DATUM, 1927.

Site Access Route: Proceed north on Mercury Highway to 3-03 Road, turn right (east). Proceed approximately 1.2 miles to 3-05 Road, turn left (north). Proceed 1.9 miles to a dirt road, turn right (east). Proceed 0.9 mile to another dirt road (if you come to a fork in the road, you have gone too far). Turn left (north) onto the dirt road, and then turn right (east) after 0.1 mile. Proceed to the high-voltage fence line. The berm where the tanks were located is $365 \mathrm{ft}$ east of the fence.

\begin{tabular}{|l|l|}
\hline \multicolumn{1}{|c|}{ Waste Item(s) Originally at Site } & Apparent Waste Type* \\
\hline ASTs & Other \\
\hline
\end{tabular}

* Ordinary, Scrap Metal, Asbestos, PCBs, Salvageable, Hazardous, Radioactive, Mixed, Unknown, Other

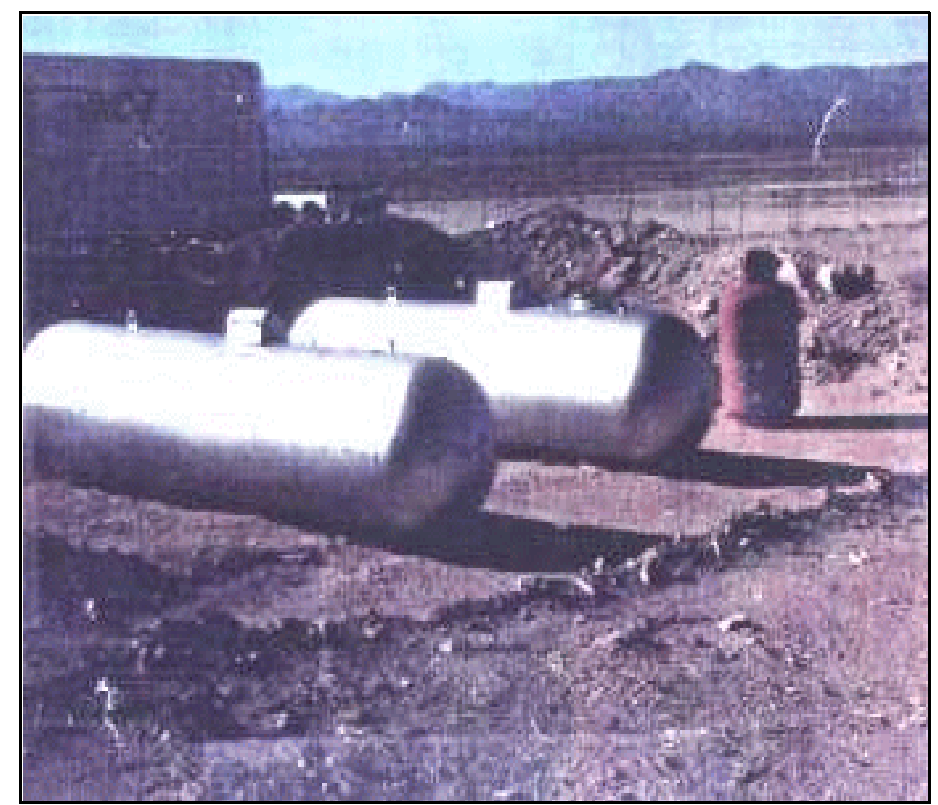

CAS Prior to Cleanup

Photograph date: 11/27/1990

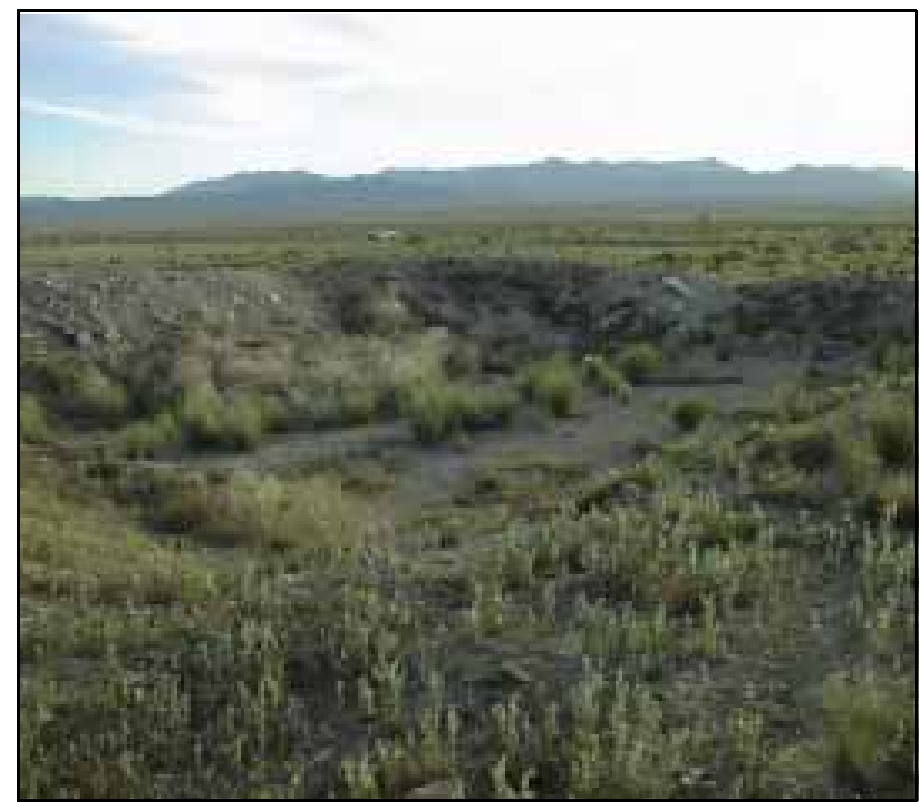

CAS After Cleanup

Photograph date: 05/09/2000

Current Site Description/Observations: The site was originally identified by REECo on November 27, 1990, as three tanks used for gas sampling. Documentation dated May 14, 1992, states that these ASTs were removed by LLNL. An ITLV field crew visited the site on July 15, 1998, and confirmed that the tanks were no longer present. A photograph matching the original REECo photograph was taken on May 9, 2000. The building is no longer present but the bermed area remains.

No Further Action Required at Corrective Action Site

Brad Jackson (Industrial Sites Project Manager)

Signature Approved, 29 June 2000 


\section{FFACO CORRECTIVE ACTION SITE Housekeeping Closure Verification Form}

CAU 119 Housekeeping Closure Report

Revision: 0

Date: $06 / 27 / 2000$

Page 10 of 20

Closure Verification Date: July 15, 1998

CAS Number: 07-99-04

CAU Number: 119

General Location: U-7be

Elevation: $1,224 \mathrm{~m}$

Latitude: 37.099670000

Northing: 4106167

Longitude: -116.028488333

Easting: 586332

Coordinate/Elevation Data Obtained from NORTH AMERICAN DATUM, 1927.

Site Access Route: Proceed north on Mercury Highway to 7-01 Road, turn right (northeast). Proceed 0.6 mile to the

North-South Access Road. Turn north and travel approximately 2.1 miles to a fork in the road. Bear right (northeast) and proceed 0.25 mile. Turn right (southeast) at the Abandon Post Shot Drilling Yard. Proceed 0.9 mile; the site marker is located on the left (east) side of the road.

\begin{tabular}{|l|l|}
\hline \multicolumn{1}{|c|}{ Waste Item(s) Originally at Site } & Apparent Waste Type* \\
\hline Gas Sampling Tank & Other \\
\hline
\end{tabular}

* Ordinary, Scrap Metal, Asbestos, PCBs, Salvageable, Hazardous, Radioactive, Mixed, Unknown, Other

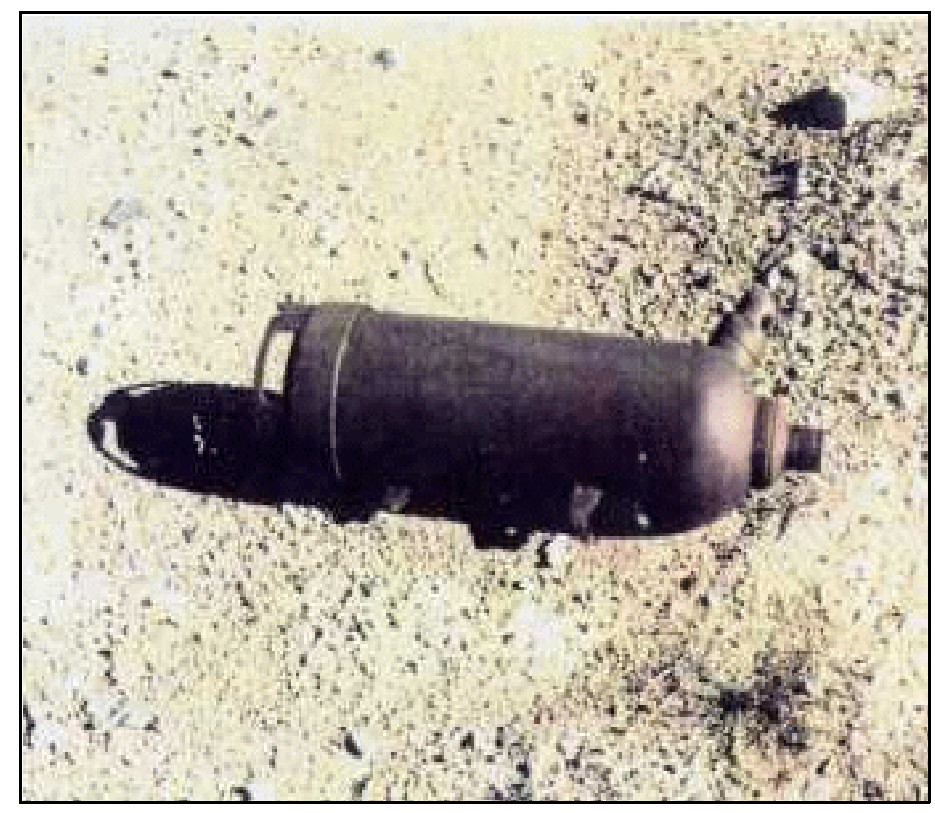

CAS Prior to Cleanup

Photograph date: 12/12/1990

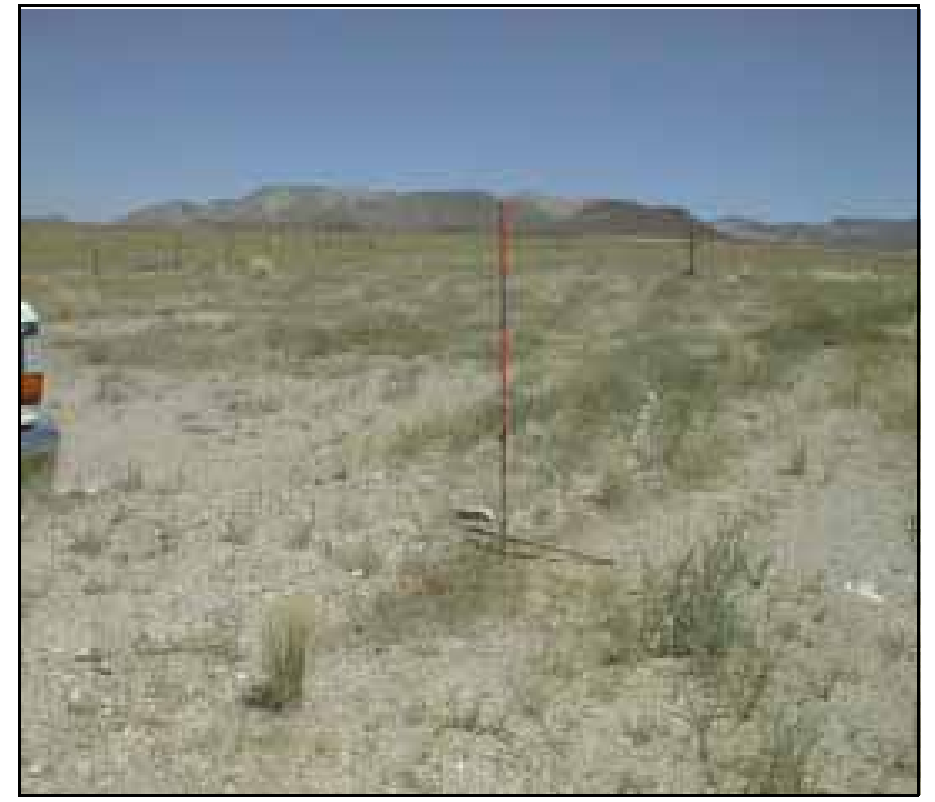

CAS After Cleanup

Photograph date: 07/15/1998

Current Site Description/Observations: The site was originally identified by REECo on December 12, 1990, as a small gas sampling tank. Documentation dated May 14, 1992, states that this tank was removed. An ITLV field crew visited the site on July 15,1998 , and confirmed that the tank was no longer present.

No Further Action Required at Corrective Action Site

Brad Jackson (Industrial Sites Project Manager)

Signature Approved, 29 June 2000 


\section{FFACO CORRECTIVE ACTION Site HouseKeEPING Closure VERIFICATION ForM}

Closure Verification Date: July 15, 1998

\author{
CAS Number: 07-99-05 \\ General Location: U-7v \\ Latitude: 37.100180000 \\ Longitude: -116.026805000
}

CAU 119 Housekeeping

Closure Report

Revision: 0

Date: $06 / 27 / 2000$

Page 11 of 20

Coordinate/Elevation Data Obtained from NORTH AMERICAN DATUM, 1927.

Site Access Route: Proceed north on Mercury Highway to the intersection of Mercury Highway, Rainier Mesa Road and 7-01 Road. Turn right (northeast) on 7-01 Road and proceed approximately 0.3 mile. Turn left (north) on a dirt road and proceed approximately 2.1 miles. Turn right (northeast) on another dirt road and proceed approximately 0.25 mile. Turn right (east) on another dirt road and proceed approximately 1.1 miles east to the north side of the U-7v crater. The site is located $60 \mathrm{ft}$ south of the access road on the north side of the U-7v crater, between the crater fence and the power line fence.

\begin{tabular}{|l|l|}
\hline \multicolumn{1}{|c|}{ Waste Item(s) Originally at Site } & \multicolumn{1}{c|}{ Apparent Waste Type* $^{*}$} \\
\hline Gas Sampling Tanks (2) & Other \\
\hline
\end{tabular}

* Ordinary, Scrap Metal, Asbestos, PCBs, Salvageable, Hazardous, Radioactive, Mixed, Unknown, Other

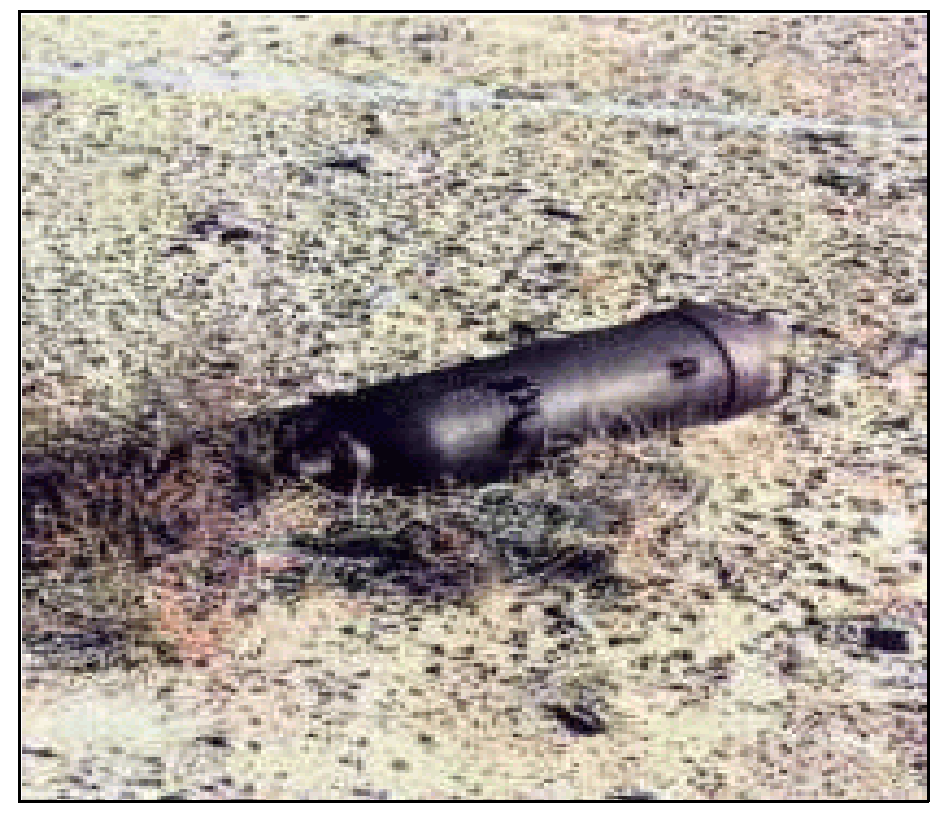

CAS Prior to Cleanup

Photograph date: $12 / 12 / 1990$

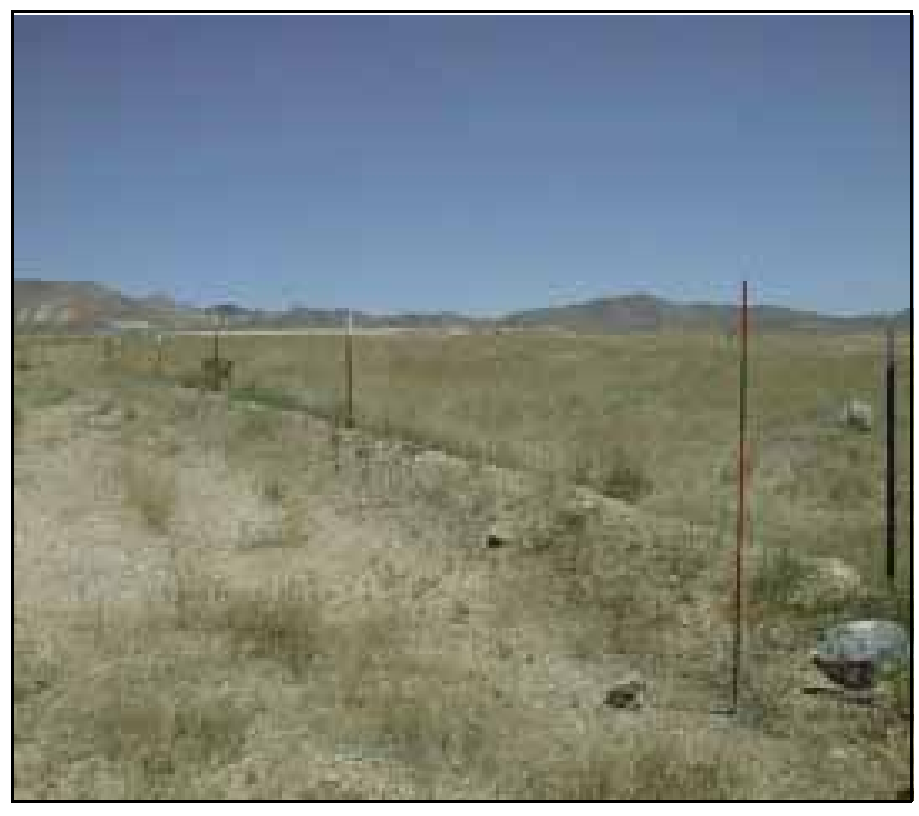

CAS After Cleanup

Photograph date: $07 / 15 / 1998$

Current Site Description/Observations: This site was originally identified by REECo on December 12, 1990, as two small tanks approximately $4 \mathrm{ft}$ long. Documentation dated May 14, 1992, states that the two tanks were removed. An ITLV field crew visited the site on July 15, 1998, and verified that the tanks had been removed.

\section{No Further Action Required at Corrective Action Site}

Brad Jackson (Industrial Sites Project Manager) Corrective Action Coordinator/Designee
Signature Approved, 29 June 2000

(Signature)
Date 


\section{FFACO CORRECTIVE ACTION SITE HoUSEKEEPING Closure VERIFICATION FORM}

Closure Verification Date: July 15, 1998

CAS Number: $08-01-02$

General Location: U-8d

Latitude: 37.165573333

Longitude: - -116.099003333
CAU 119 Housekeeping Closure Report Revision: 0

Date: $06 / 27 / 2000$

Page 12 of 20

Coordinate/Elevation Data Obtained from NORTH AMERICAN DATUM, 1927.

Site Access Route: Proceed north on Mercury Highway to Rainier Mesa Road, turn left (northwest). Proceed to 2-07 Road, turn right (east) and proceed to RSM-2L-13 sign. Turn left (north) on the dirt road and proceed approximately 0.3 mile. The site is in the northwest section of the former Area 8 Camp/Trailer park area (approximately 0.5 mile southeast of U-8d).

\begin{tabular}{|l|l|}
\hline \multicolumn{1}{|c|}{ Waste Item(s) Originally at Site } & \multicolumn{1}{c|}{ Apparent Waste Type* } \\
\hline AST & Unknown \\
\hline
\end{tabular}

* Ordinary, Scrap Metal, Asbestos, PCBs, Salvageable, Hazardous, Radioactive, Mixed, Unknown, Other

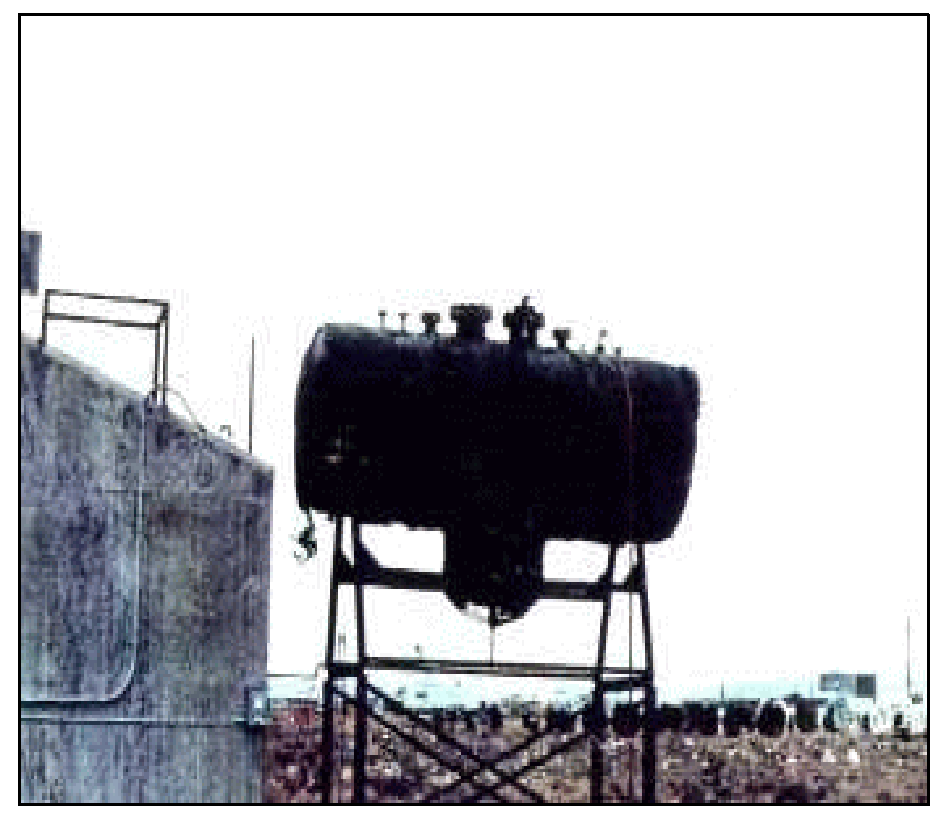

CAS Prior to Cleanup

Photograph date: 01/04/1991

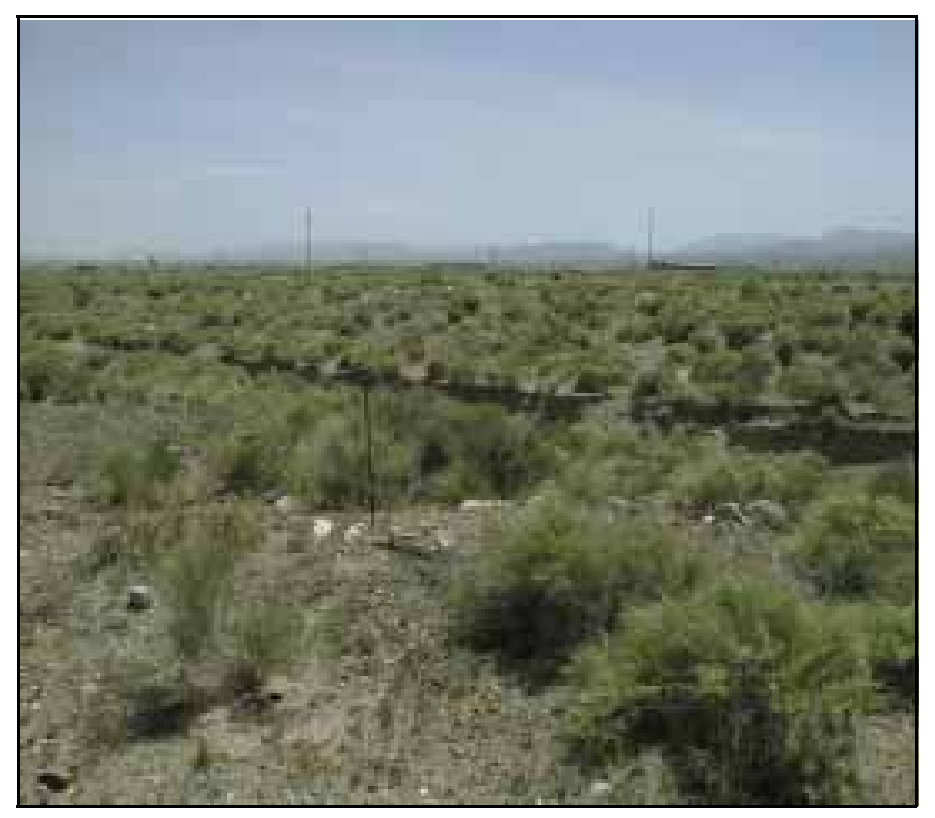

CAS After Cleanup

Photograph date: 05/10/2000

Current Site Description/Observations: The site was originally identified by REECo on January 4, 1991, as an empty AST on a stand. An ITLV field crew visited the site on July 14, 1993, and verified that the AST was present. The site was revisited on July 15, 1998; the original site marker was located but the AST and trailers had been removed. There were no stains in the area where the AST was located. An ITLV field crew returned on May 10, 2000, to photograph the site to match the original REECo photograph. It was noted that the building and cable reels have been removed.

No Further Action Required at Corrective Action Site

Brad Jackson (Industrial Sites Project Manager)

Signature Approved, 29 June 2000

Corrective Action Coordinator/Designee

(Signature)

Date 


\section{FFACO CORRECTIVE ACTION Site HoUSEKEEPING Closure VERIFICATION FORM}

Closure Verification Date: July 15, 1998

CAS Number: 08-01-03

General Location: U-8d

Latitude: 37.165573333

Longitude: -116.099003333
CAU 119 Housekeeping

Closure Report

Revision: 0

Date: $06 / 27 / 2000$

Page 13 of 20

Coordinate/Elevation Data Obtained from NORTH AMERICAN DATUM, 1927.

Site Access Route: Proceed north on Mercury Highway to Rainier Mesa Road, turn left (northwest). Proceed to 2-07 Road, turn right (east) and proceed to RSM-2L-13. Turn left (north) on the dirt road and proceed approximately 0.3 mile. The site is in the northwest section of the former Area 8 Camp/Trcailer park area (approximately 0.5 mile southeast of U-8d).

\begin{tabular}{|l|l|}
\hline \multicolumn{1}{|c|}{ Waste Item(s) Originally at Site } & Apparent Waste Type* \\
\hline AST & Unknown \\
\hline
\end{tabular}

* Ordinary, Scrap Metal, Asbestos, PCBs, Salvageable, Hazardous, Radioactive, Mixed, Unknown, Other

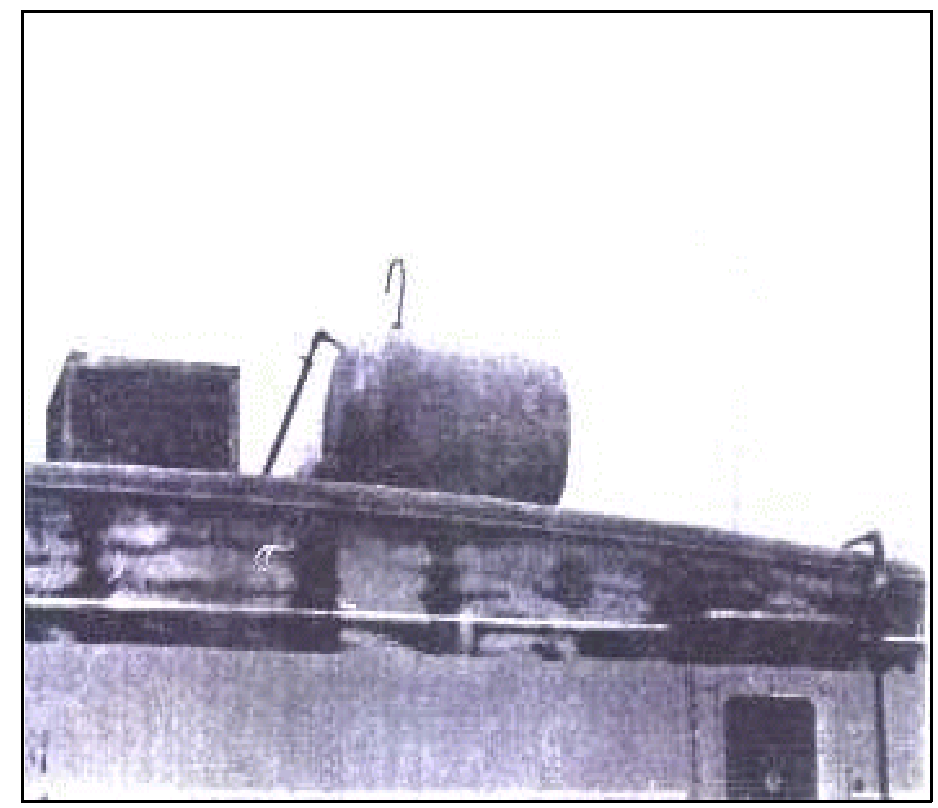

CAS Prior to Cleanup

Photograph date: 01/04/1991

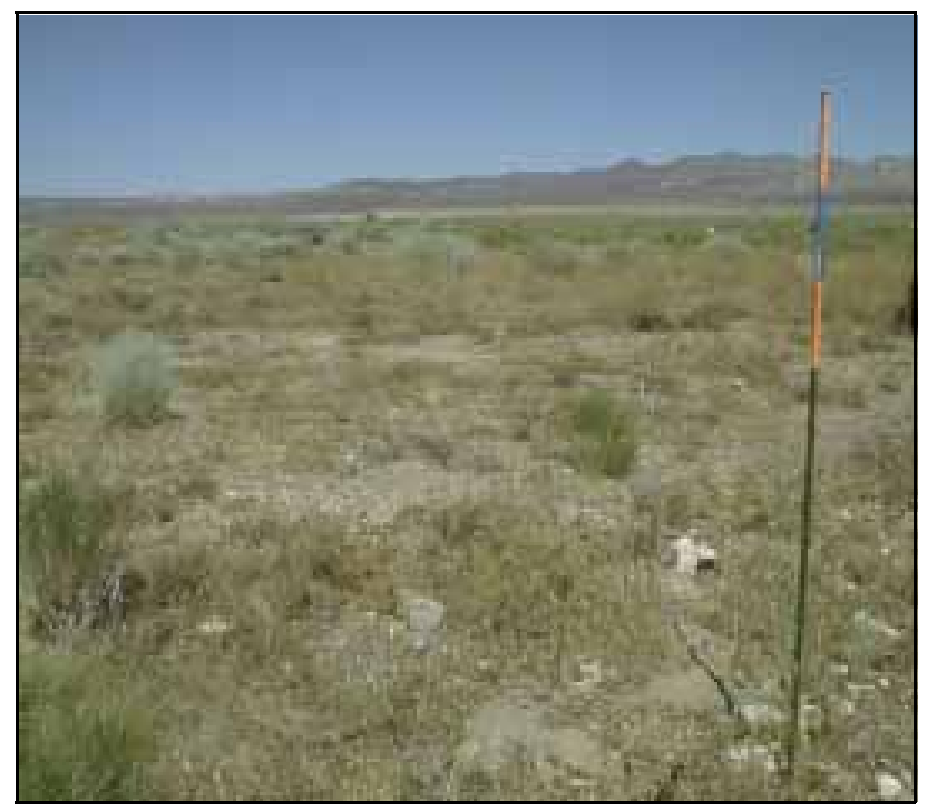

CAS After Cleanup

Photograph date: 07/15/1998

Current Site Description/Observations: The site was originally identified by REECo on January 4, 1991, as an AST on a stand. An ITLV field crew visited the site on July 14, 1993, and verified that the AST was present on top of the trailer. The site was revisited on July 15, 1998; the original site marker was located but the AST and trailers had been removed.

No Further Action Required at Corrective Action Site

Brad Jackson (Industrial Sites Project Manager)

Signature Approved, 29 June 2000 


\section{FFACO Corrective ACTION Site HouseKeEPING Closure Verification Form}

Closure Verification Date: September 14, 1993

CAS Number: 18-02-01

General Location: Area 17 Camp Gas Station

Latitude: 37.1610164

Longitude: -116.2620270
CAU 119 Housekeeping

Closure Report

Revision: 0

Date: $06 / 27 / 2000$

Page 14 of 20

Coordinate/Elevation Data Obtained from NORTH AMERICAN DATUM, 1927.

Site Access Route: Proceed north on Mercury Highway to Tippipah Highway, turn left (northwest). Proceed to Pahute Mesa Road, turn left (west). Proceed past Stockade Wash Road approximately 1.3 miles to the intersection of Pahute Mesa Road and Road 18-B (the other name of the intersection is Pahute C.P. [17 Camp]). The gas station is at RSM-18P-39. The site is located behind the gas station (southwest) in a small clearing.

\begin{tabular}{|l|l|}
\hline \multicolumn{1}{|c|}{ Waste Item(s) Originally at Site } & Apparent Waste Type* \\
\hline USTs (2) & Hazardous \\
\hline
\end{tabular}

* Ordinary, Scrap Metal, Asbestos, PCBs, Salvageable, Hazardous, Radioactive, Mixed, Unknown, Other

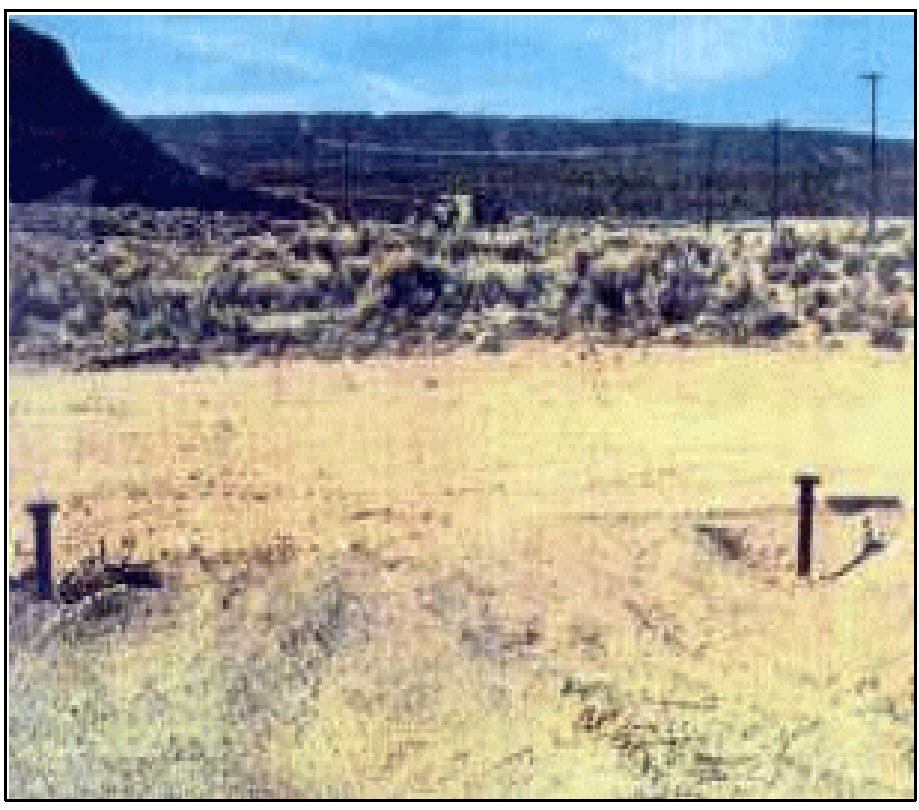

CAS Prior to Cleanup

Photograph date: 01/08/1991

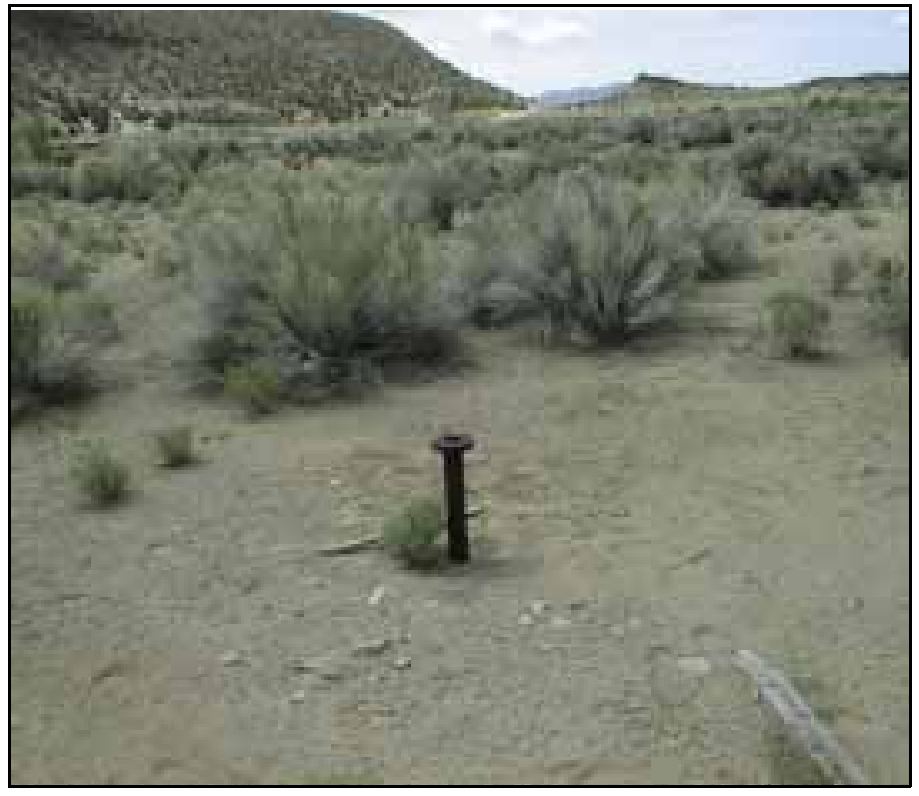

CAS After Cleanup

Photograph date: 05/09/2000

Current Site Description/Observations: The site was originally identified by REECo on January 8, 1991, as underground fuel tanks located at the Camp 17 Gas Station. It was also stated on the forms that the tanks had been removed. Documentation dated October 11, 1991, states that the two 10,000 gallon USTs associated with this site were removed in December 1989 (see Attachment A). An ITLV field crew visited the site on September 14, 1993. The crew noted that four metal posts remained at the previous tank locations. There were no indications of staining in the area of the posts. A photograph of the site was taken by an ITLV field crew on May 9, 2000.

\section{$\checkmark \quad$ No Further Action Required at Corrective Action Site}

Brad Jackson (Industrial Sites Project Manager)

Signature Approved, 29 June 2000 


\section{FFACO CORRECTIVE ACTION Site HouseKeEPING Closure VERIFICATION FoRM}

CAU 119 Housekeeping Closure Report

Revision: 0

Date: $06 / 27 / 2000$

Page 15 of 20

Closure Verification Date: September 14, 1993

CAS Number: 18-02-02

General Location: Area 17 Camp Gas Station

Latitude: 37.1612775

Longitude: -116.2628663

\author{
CAU Number: 119 \\ Elevation: 1,761 \\ Northing: 6267594 \\ Easting: 535785
}

Coordinate/Elevation Data Obtained from NORTH AMERICAN DATUM, 1927.

Site Access Route: Proceed north on Mercury Highway to Tippipah Highway, turn left (northwest). Proceed to Pahute Mesa Road, turn left (west). Proceed past Stockade Wash Road approximately 1.3 miles to the intersection of Pahute Mesa Road and Road 18-B (the other name of the intersection is Pahute C.P. [17 Camp]). The gas station is at RSM-18P-39. The site is approximately $450 \mathrm{ft}$ (west) of the gas station.

\begin{tabular}{|c|l|}
\hline Waste Item(s) Originally at Site & \multicolumn{1}{c|}{ Apparent Waste Type* $^{*}$} \\
\hline AST (misidentified as an UST in the FFACO) & Unknown \\
\hline
\end{tabular}

* Ordinary, Scrap Metal, Asbestos, PCBs, Salvageable, Hazardous, Radioactive, Mixed, Unknown, Other

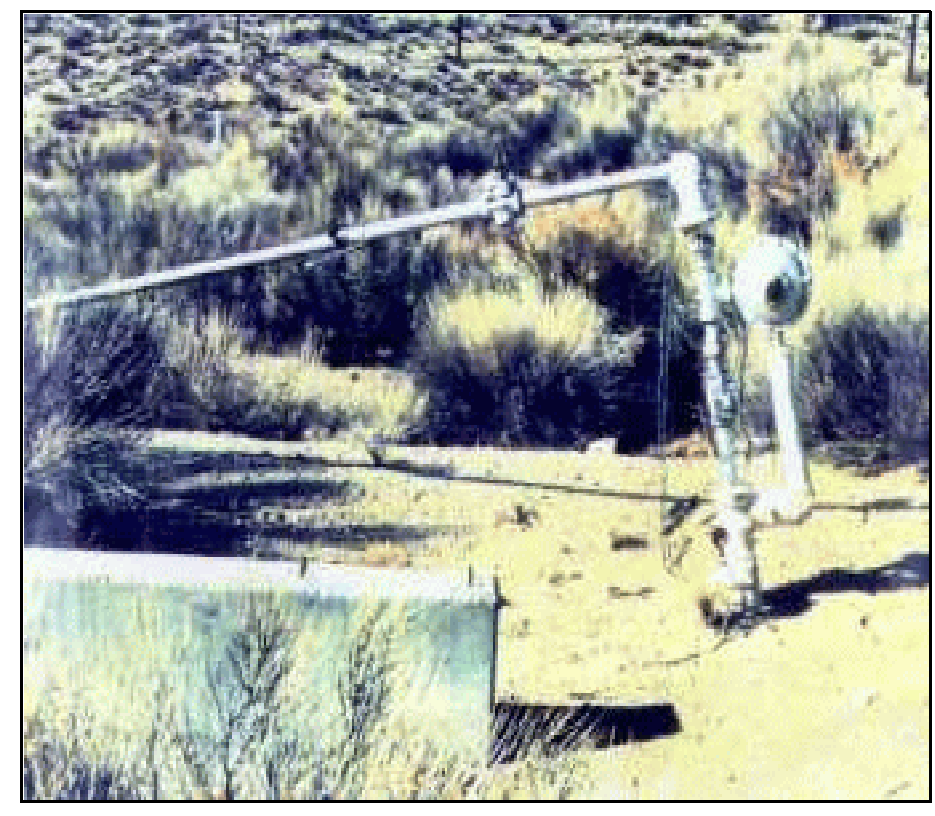

CAS Prior to Cleanup

Photograph date: 01/08/1991

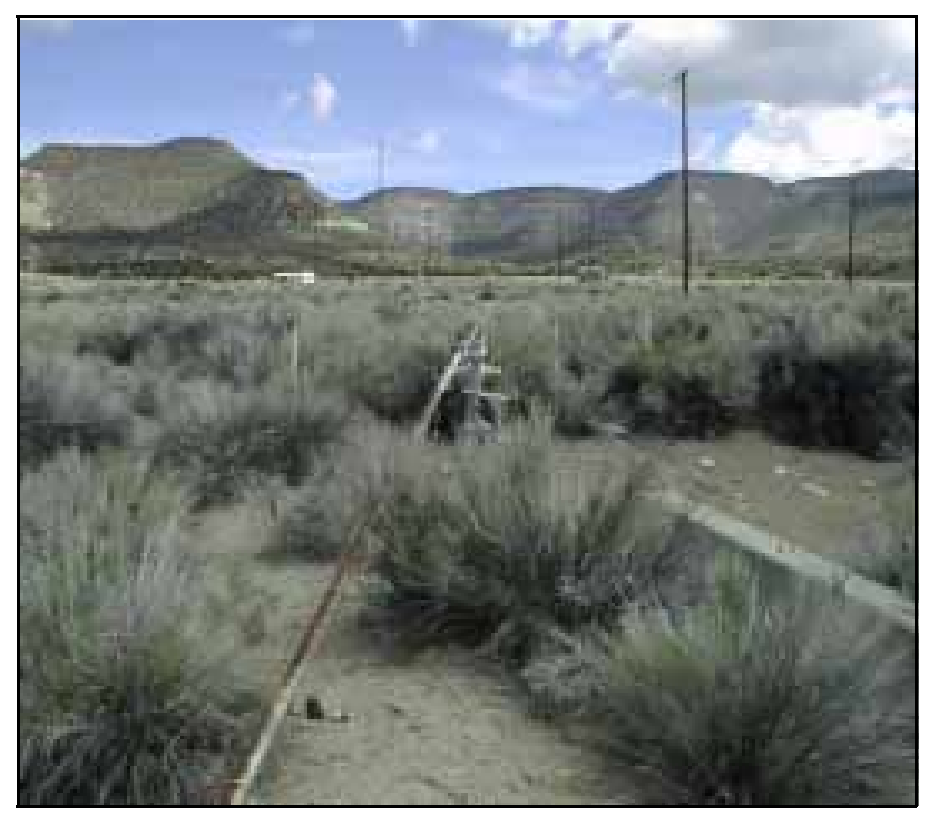

CAS After Cleanup

Photograph date: 05/09/2000

Current Site Description/Observations: The site was originally identified by REECo on January 8, 1991, as gas meter, regulator, and plumbing possibly for an UST. Documentation dated October 11, 1991, states that the site originally consisted of an AST that has since been removed. All that remains is the valve and regulator/mixer. An ITLV field crew visited the site on September 14, 1993. The crew confirmed that the tank had been removed and there was no staining evident in the area around the remaining plumbing. An ITLV field crew took a photograph of the site on May 9, 2000.

\title{
$\checkmark \quad$ No Further Action Required at Corrective Action Site
}

Brad Jackson (Industrial Sites Project Manager)

Signature Approved, 29 June 2000 


\section{FFACO CORRECTIVE ACTION SITE Housekeeping Closure VERIFICATION FoRM}

Closure Verification Date: March 10, 1998

CAS Number: 25-01-09

General Location: Building 3100, Reactor-Maintenance, Assembly, and Disassembly (R-MAD) Facility

Latitude: 36.815170410

Longitude: -116.239027100
CAU 119 Housekeeping Closure Report

Revision: 0

Date: $06 / 27 / 2000$

Page 16 of 20

Coordinate/Elevation Data Obtained from NORTH AMERICAN DATUM, 1927.

Site Access Route: From Mercury, proceed southwest on Jackass Flats Road. Follow the road as it continues west and then north to the Area 25 Guard Gate (Guard Station 500). At this point the road turns into C Road. Continue straight (north) on C Road. Turn right (east) on Road G and follow to the R-MAD complex. The site is $110 \mathrm{ft}$ south of the northeast corner fence post.

\begin{tabular}{|l|l|}
\hline \multicolumn{1}{|c|}{ Waste Item(s) Originally at Site } & \multicolumn{1}{c|}{ Apparent Waste Type* $^{\text {Apann }}$} \\
\hline AST & Unknown \\
\hline
\end{tabular}

* Ordinary, Scrap Metal, Asbestos, PCBs, Salvageable, Hazardous, Radioactive, Mixed, Unknown, Other

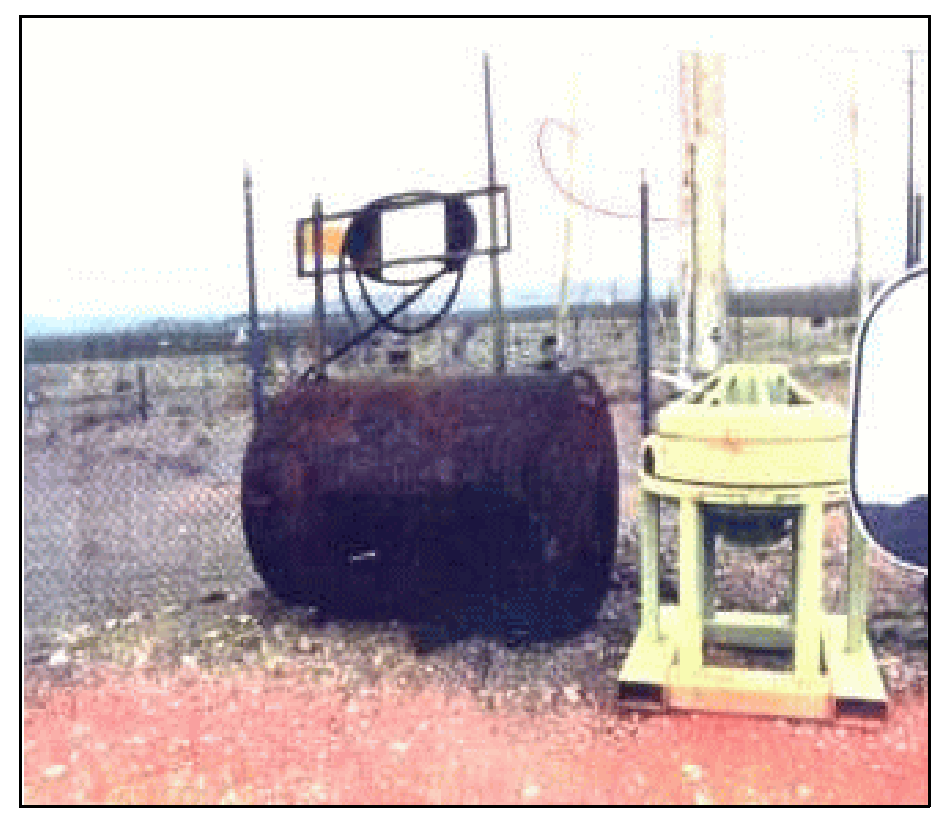

CAS Prior to Cleanup

Photograph date: 12/04/1990

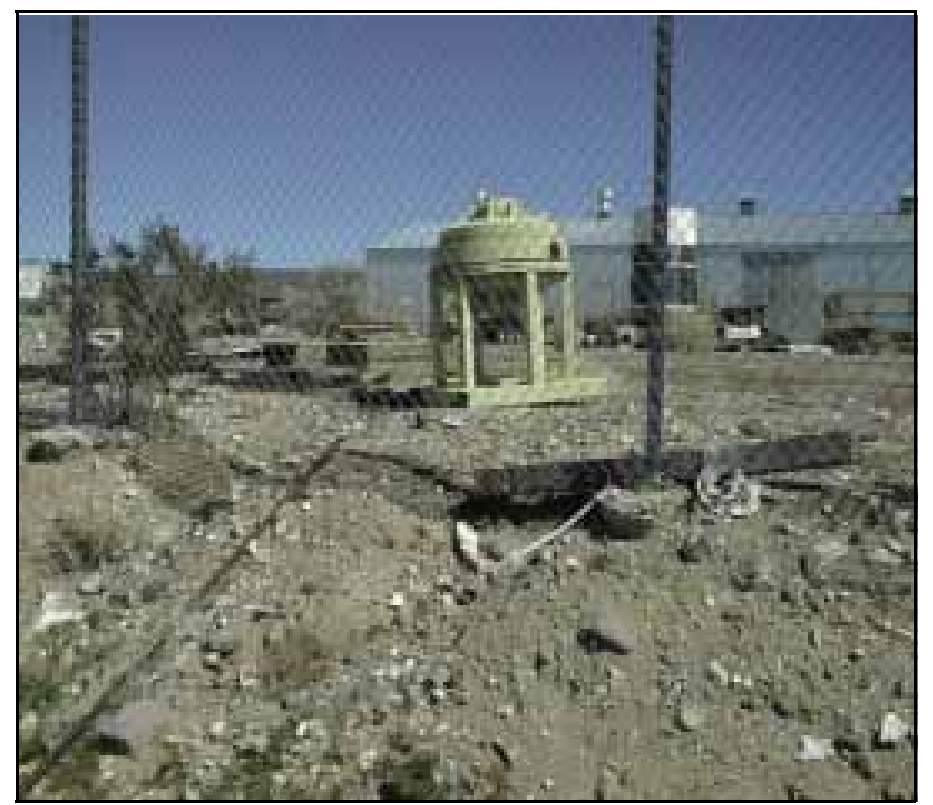

CAS After Cleanup

Photograph date: 03/10/1998

Current Site Description/Observations: The site was originally identified by REECo on December 4, 1990, as a diesel tank located in the storage yard at the R-MAD Facility. An ITLV field crew visited the site on March 10, 1998, and confirmed that the AST had been removed. There was no staining identified where the AST was formerly located.

\section{No Further Action Required at Corrective Action Site}

Brad Jackson (Industrial Sites Project Manager)

Signature Approved, 29 June 2000 


\section{FFACO CORRECTIVE ACTION Site HouseKeEPING Closure VERIFICATION ForM}

Closure Verification Date: March 5, 1998

CAS Number: 25-01-11

General Location: $\quad$ X-Tunnel

Latitude: 36.724773830

Longitude: $\quad-116.328511900$
CAU 119 Housekeeping Closure Report

Revision: 0

Date: $06 / 27 / 2000$

Page 17 of 20

Coordinate/Elevation Data Obtained from NORTH AMERICAN DATUM, 1927.

Site Access Route: From Mercury, proceed southwest on Jackass Flats road for approximately 20.9 miles to the Area 25 Guard Gate. Turn left (west) onto Lathrop Wells road. Travel approximately 5.8 miles to the X-Tunnel road and turn left (north). Travel approximately 2.2 miles on X-tunnel road to the locked gate 25-C12 (call OCC for access). Proceed 1 mile beyond gate to storage yard and continue up the hill to the X-Tunnel portal area.

\begin{tabular}{|l|l|}
\hline \multicolumn{1}{|c|}{ Waste Item(s) Originally at Site } & \multicolumn{1}{c|}{ Apparent Waste Type* } \\
\hline AST & Hazardous \\
\hline
\end{tabular}

* Ordinary, Scrap Metal, Asbestos, PCBs, Salvageable, Hazardous, Radioactive, Mixed, Unknown, Other

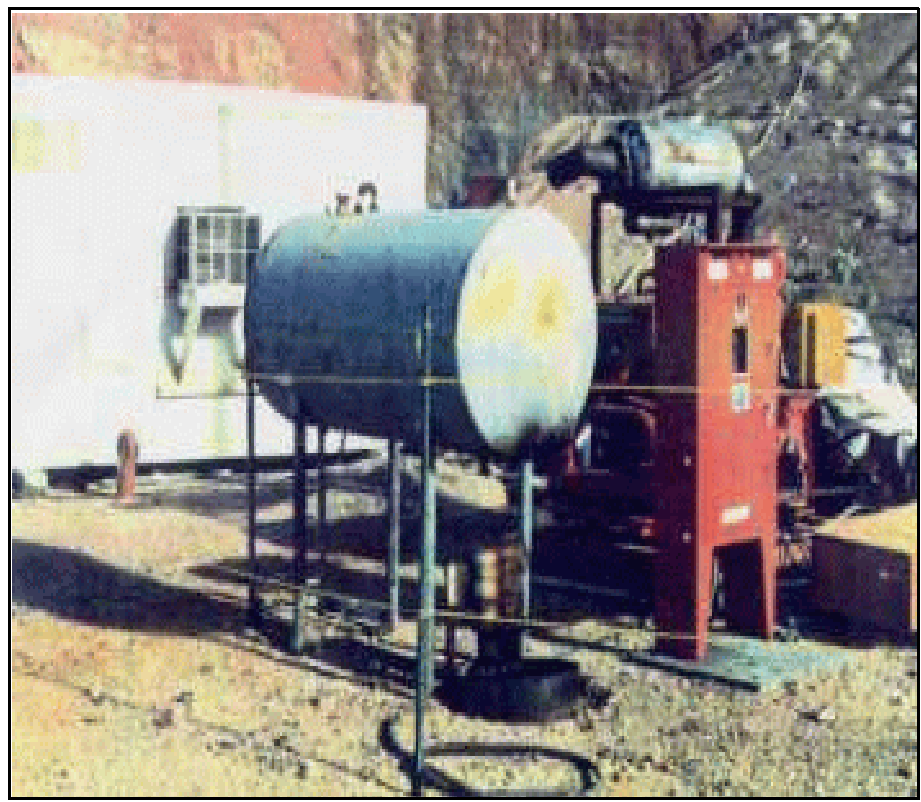

CAS Prior to Cleanup

Photograph date: 12/21/1990

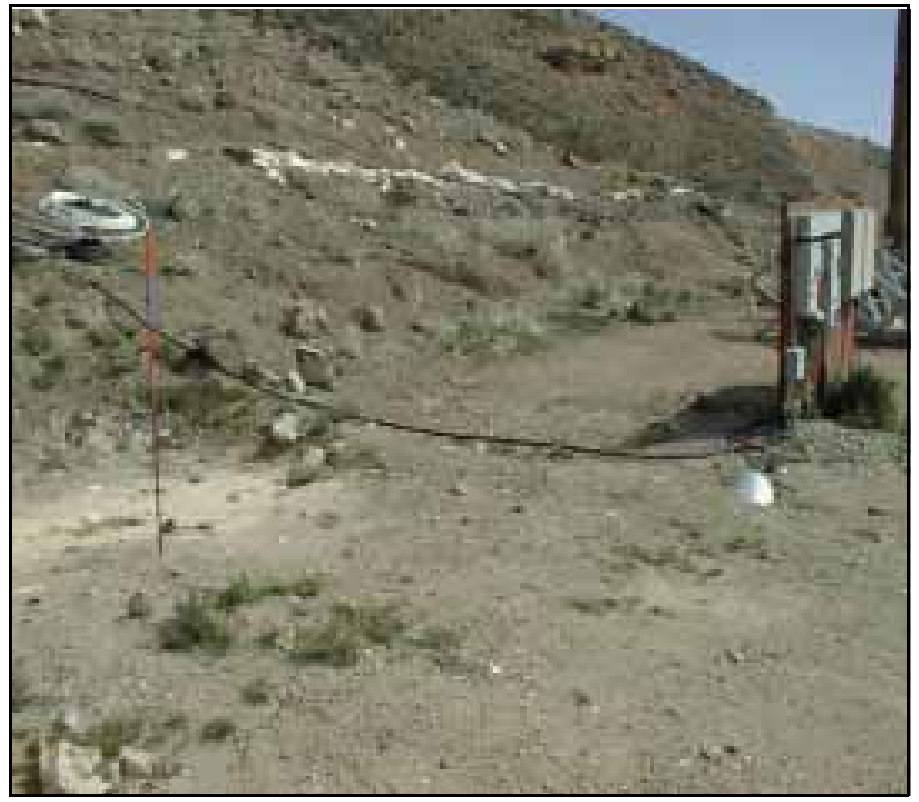

CAS After Cleanup

Photograph date: 03/05/1998

Current Site Description/Observations: The site was originally identified by REECo on December 21, 1990, as an AST containing diesel fuel. An ITLV field crew visited the site on March 5, 1998, and confirmed that the tank had been removed and there was no staining in the area where the tank was previously located. 


\section{FFACO CORRECTIVE ACTION Site HouseKeEPING Closure VERIFICATION Form}

CAU 119 Housekeeping Closure Report

Revision: 0

Date: $06 / 27 / 2000$

Page 18 of 20

Closure Verification Date: May 28, 1998

CAS Number: 25-01-14

CAU Number: 119

General Location: Engine-Maintenance, Assembly, and Disassembly

Elevation: $1,027 \mathrm{~m}$

(E-MAD) Facility

Northing: 4073450

Latitude: 36.806676270

Easting: 562073

Longitude: -116.304146100

Coordinate/Elevation Data Obtained from NORTH AMERICAN DATUM, 1927.

Site Access Route: From Mercury, proceed southwest on Jackass Flats Road. Follow the road as it continues west and then north to the Area 25 Guard Gate (Guard Station 500). At this point the road turns into C Road. Continue north (straight) on C Road. Turn left (west) on H Road. Turn left (south) on E-MAD Road and proceed to the E-MAD Facility. The tank was located on the asphalt area on the north side of the E-MAD Building.

\begin{tabular}{|l|l|}
\hline \multicolumn{1}{|c|}{ Waste Item(s) Originally at Site } & \multicolumn{1}{c|}{ Apparent Waste Type* $^{\text {Aptan }}$} \\
\hline Contaminated Storage Tank & Unknown \\
\hline
\end{tabular}

* Ordinary, Scrap Metal, Asbestos, PCBs, Salvageable, Hazardous, Radioactive, Mixed, Unknown, Other

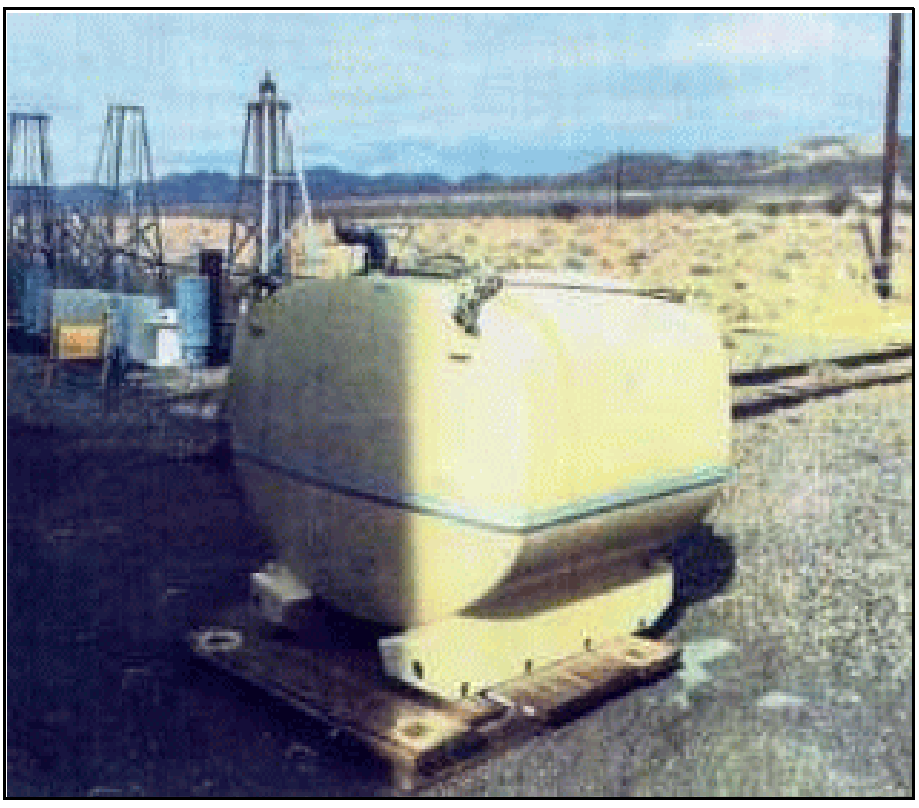

CAS Prior to Cleanup

Photograph date: 12/20/1990

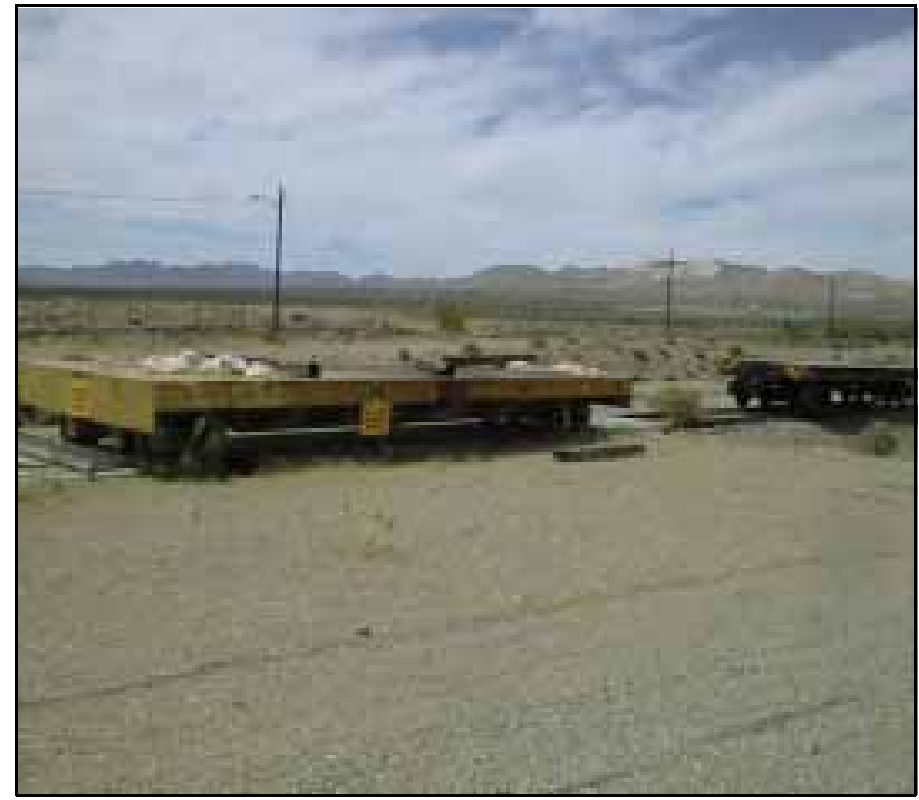

CAS After Cleanup

Photograph date: 05/28/1998

Current Site Description/Observations: The site was originally identified by REECo on December 20, 1990, as an empty contaminated storage tank. An ITLV field crew visited the site on May 28, 1998, and verified that the tank had been removed. No Further Action Required at Corrective Action Site 


\section{FFACO CORRECTIVE ACTION SITE HouseKeEPing Closure Verification Form}

Closure Verification Date: June 2, 1998

CAS Number: 25-23-14

General Location: X-Tunnel Portal

Latitude: 36.724783333

Longitude: -116.327816667
CAU 119 Housekeeping

Closure Report

Revision: 0

Date: $06 / 27 / 2000$

Page 19 of 20

\section{Coordinate/Elevation Data Obtained from NORTH AMERICAN DATUM, 1927.}

Site Access Route: From Mercury, proceed southwest on Jackass Flats Road. Follow the road as it continues west and then north to the Area 25 Guard Gate (Guard Station 500). Turn left (west) onto Lathrop Wells Road and travel approximately 8.1 miles to X-Tunnel Road. Turn left (north) on X-Tunnel Road and travel approximately 2.2 miles to the locked Gate 25-C12 (call OCC for access). Proceed 1 mile beyond gate to storage yard and continue up the hill to the portal area.

\begin{tabular}{|l|l|}
\hline \multicolumn{1}{|c|}{ Waste Item(s) Originally at Site } & \multicolumn{1}{c|}{ Apparent Waste Type* } \\
\hline Trailer Tank & Unknown \\
\hline
\end{tabular}

* Ordinary, Scrap Metal, Asbestos, PCBs, Salvageable, Hazardous, Radioactive, Mixed, Unknown, Other

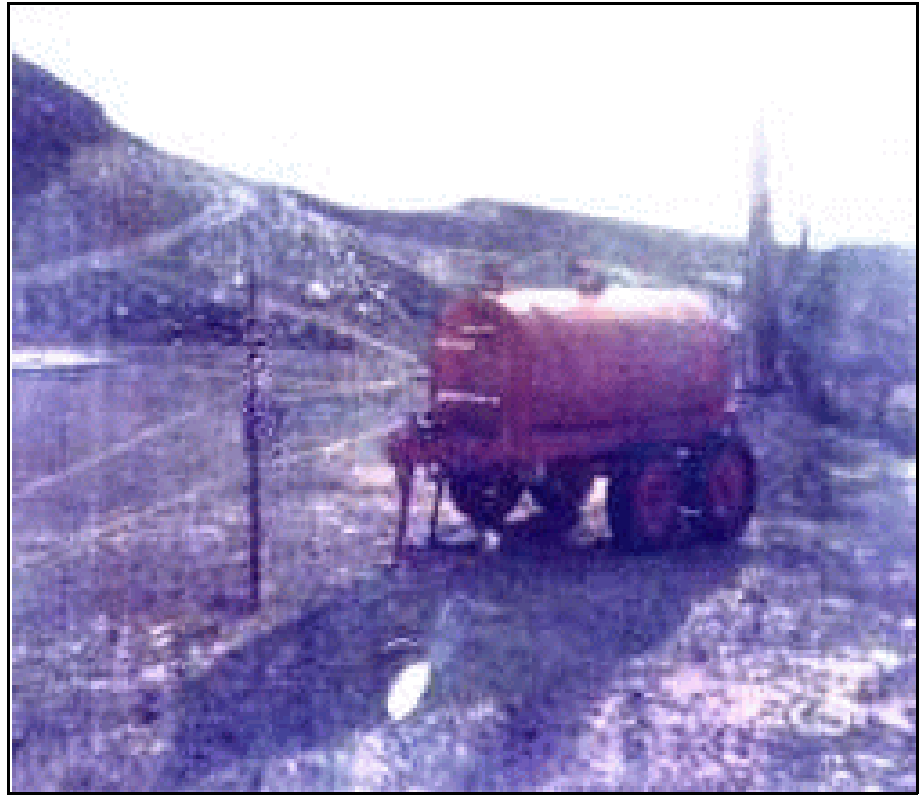

CAS Prior to Cleanup Photograph date: 12/21/1990

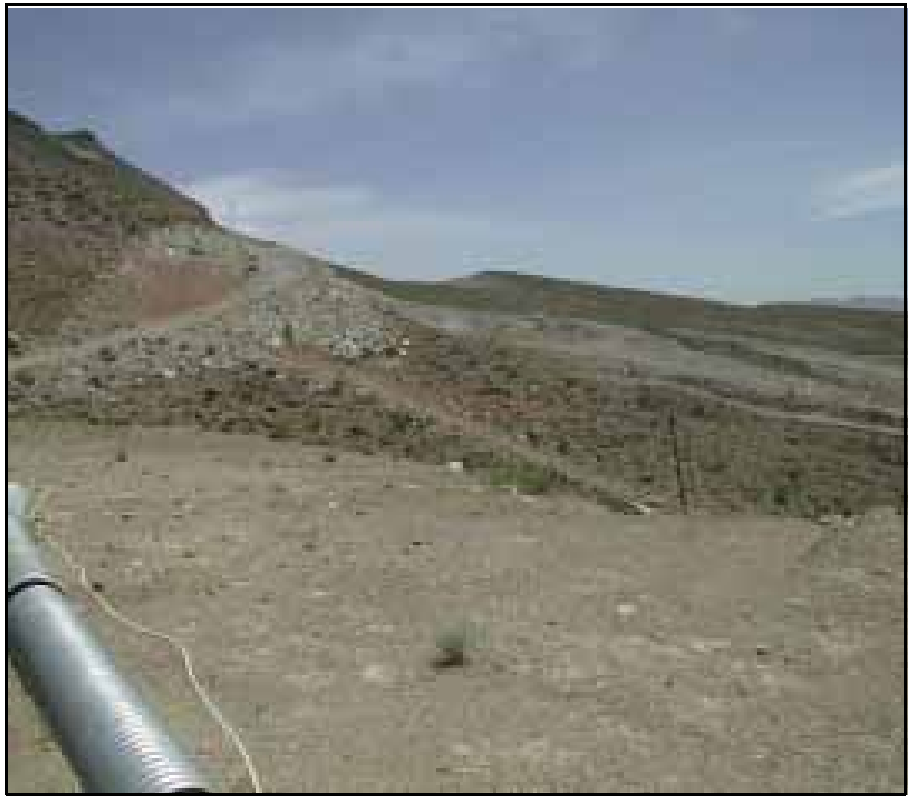

CAS After Cleanup

Photograph date: 05/10/2000

Current Site Description/Observations: The site was originally identified by REECo on December 21, 1990, as a trailer tank with possible depleted uranium contamination. An interview was conducted concerning this site, and it was believed that the tank may have been buried or emptied in a pit just off the access road, below the portal. An ITLV field crew visited the site on June 2, 1998, and confirmed that the tank had been removed. No surface stains or environmental concerns were observed. An ITLV field crew returned on May 10, 2000, to photograph the site to match the original REECo photograph.

\section{No Further Action Required at Corrective Action Site}

Brad Jackson (Industrial Sites Project Manager)

Signature Approved, 29 June 2000

Corrective Action Coordinator/Designee

(Signature)

Date 


\section{FFACO CORRECTIVE ACTION Site HouseKeEPING Closure VerifiCATION ForM}

Closure Verification Date: June 21, 2000

CAS Number: 26-02-03

General Location: Building 2201

Latitude: 36.815563560

Longitude: -116.164839000
CAU 119 Housekeeping

Closure Report

Revision: 0

Date: $06 / 27 / 2000$

Page 20 of 20

Coordinate/Elevation Data Obtained from NORTH AMERICAN DATUM, 1927.

Site Access Route: From Mercury, proceed southwest on Jackass Flats Road. Follow the road as it continues west and then north to the Area 25 Guard Gate (Guard Station 500). After passing the Area 25 Guard Station 500, turn right (east) on Cane Springs Road. Continue approximately 6.1 miles to the top of the pass, turn left (south) and proceed to the top of the road to Building 2201. The site is located inside a fenced area.

\begin{tabular}{|l|l|}
\hline \multicolumn{1}{|c|}{ Waste Item(s) Originally at Site } & \multicolumn{1}{|c|}{ Apparent Waste Type* $^{*}$} \\
\hline UST & Unknown \\
\hline
\end{tabular}

* Ordinary, Scrap Metal, Asbestos, PCBs, Salvageable, Hazardous, Radioactive, Mixed, Unknown, Other

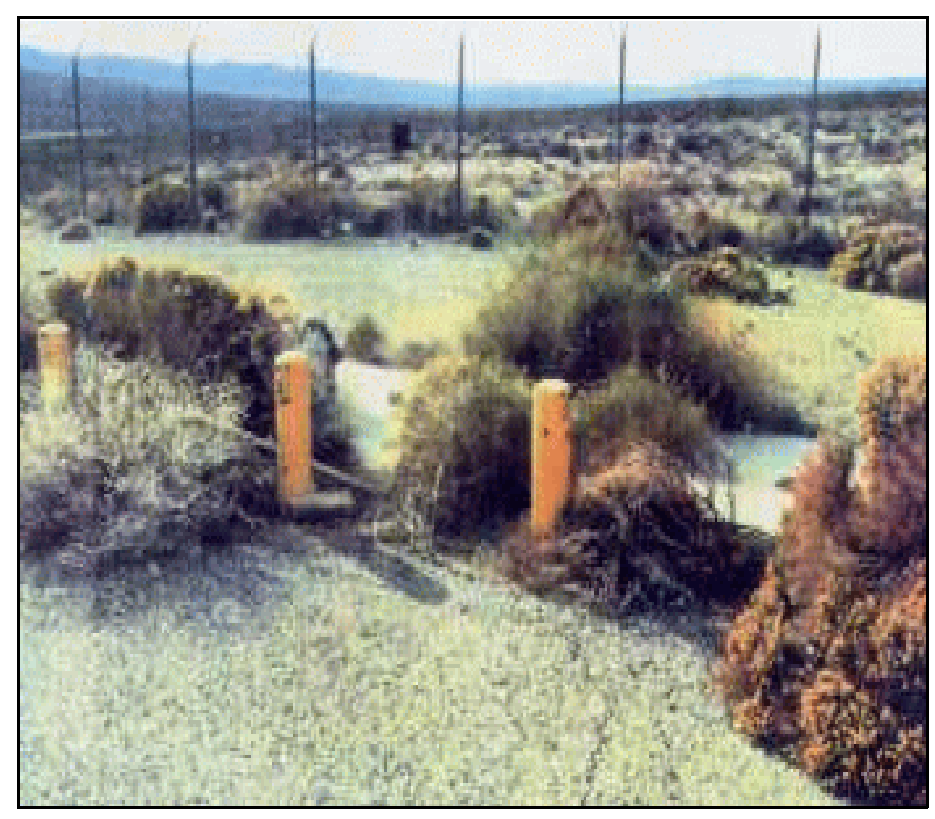

CAS Prior to Cleanup

Photograph date: 12/04/1990

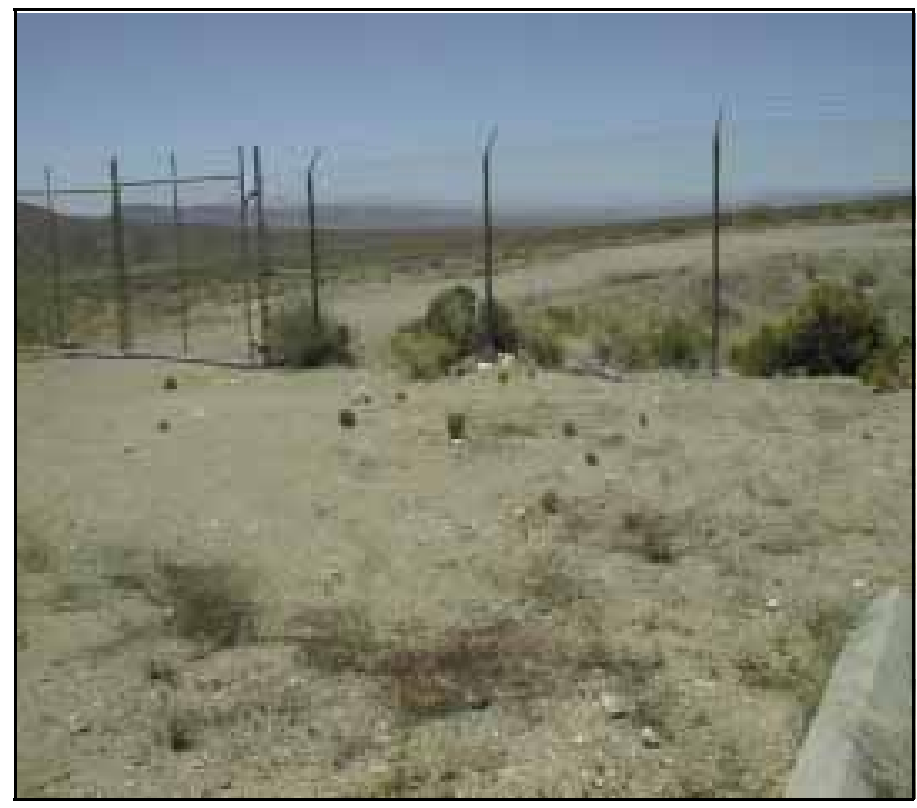

CAS After Cleanup

Photograph date: 06/21/2000

Current Site Description/Observations: The site was originally identified by REECo on December 4, 1990, as an UST of unknown size and contents. An ITLV field crew visited the site on May 11, 1995, and noted that the tank was in the process of being removed. The site was revisited and photographed on June 21, 2000. A notification of tank closure was submitted by the U.S. Department of Energy, Nevada Operations Office on October 23, 1995. Documentation dated November 6, 1995, states that the Nevada Division of Environmental Protection accepted the final closure of this site.

No Further Action Required at Corrective Action Site

Brad Jackson (Industrial Sites Project Manager)

Corrective Action Coordinator/Designee
Signature Approved, 29 June 2000

(Signature)
Date 
Attachment A

\section{Verification of Tank Removal}


Post Office Box 98521 - Las Vegas, NV 89193-8521

53 INEPLY REEER TO

$530-03-17$

OCT 111999

Joseph N. Fiore, Director

Environmental Restoration and

Waste Management Division

DOE Field Office, Nevada

Post Office Box 98518

Las Vegas, NV 89193-8518

TRANSMITTAL OF PRELIMINARY INVESTIGATION OF WRITE UP NUMBER

18-02-01 FROM SURVEY OF INACTIVE AND ABANDONED SITES

The Reynolds Electrical \& Engineering Company, Inc., Environmental Compliance Office has completed a preliminary investigation of the Underground Storage Tanks (USTs) described in Nevada Test Site Inventory of Inactive And Abandoned Facilities And Waste Sites (DOE/NV/10630-18) as write up number 18-02-01. The item described was confirmed through record verifications to be the site of two 10,000 gallon fuel tanks removed in December 1989 as part of the ongoing UST program.

Notification of removal of the tanks (Tank Numbers 18-1 and 18-2) was submitted to the Nevada Division of Environmental Protection on December 21, 1989.

Further investigation, assessment, sampling, or allocation of resources is not needed for write up number 18-02-01 because analytical results for the tank site closure indicated Total Petroleum Hydrocarbon concentrations below the $100 \mathrm{mg} / \mathrm{kg}$ Action Level for cleanup established by the state of Nevada.

If you have any questions, please contact D. D. Madsen of my staff at 295-7211.

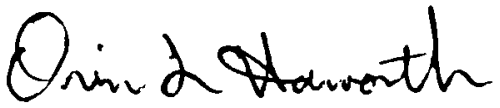

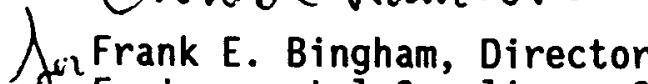

If Environmental Compliance Office

FEB :DDM:M9157:bm

cy: J. D. Stewart, DOE/NTS, M/S 701

J. L. Appenzeller-Wing, DOE/NV, M/S 505

D. R. Elle, DOE/NV, M/S 505

S. A. Mellington, DOE/NV, M/S 505 
Attachment B

\section{Document Review Sheets}




\section{NEVADA ENVIRONMENTAL RESTORATION PROJECT DOCUMENT REVIEW SHEET}

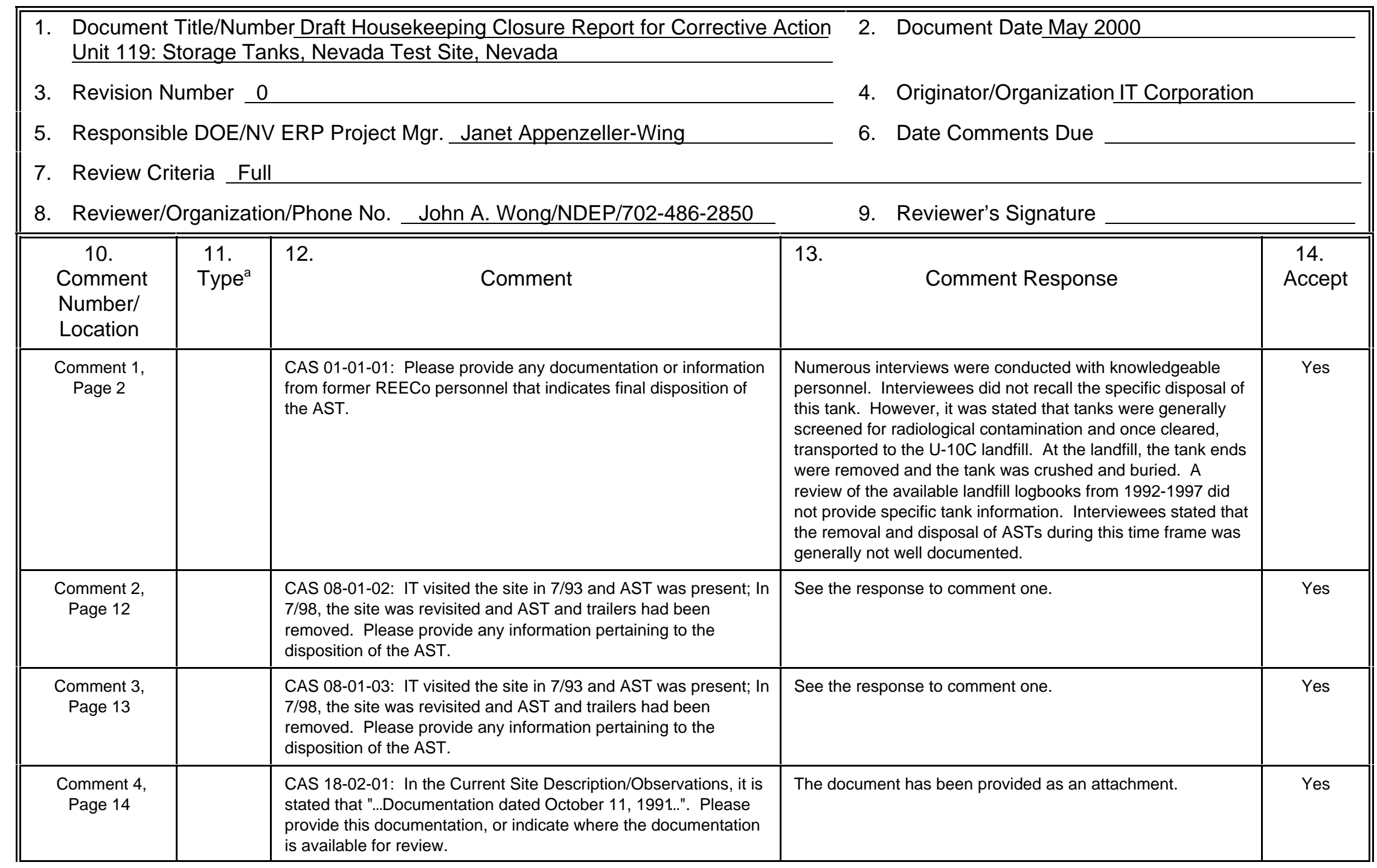

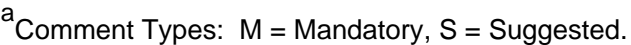

Return Document Review Sheets to DOE/NV Environmental Restoration Division, Attn: QAC, M/S 505. 


\section{NEVADA ENVIRONMENTAL RESTORATION PROJECT DOCUMENT REVIEW SHEET}

Document Title/Number Draft Housekeeping Closure Report for Corrective Action Unit 119: Storage Tanks, Nevada Test Site, Nevada

Reviewer/Organization John A. Wong/NDEP/702-486-2850

\begin{tabular}{|c|c|c|c|c|}
\hline $\begin{array}{c}10 . \\
\text { Comment } \\
\text { Number/ } \\
\text { Location }\end{array}$ & $\begin{array}{c}11 . \\
\text { Type }^{a}\end{array}$ & Comment & Comment Response & $\begin{array}{c}14 . \\
\text { Accept }\end{array}$ \\
\hline $\begin{array}{l}\text { Comment } 5 \\
\text { Page } 15\end{array}$ & & $\begin{array}{l}\text { CAS 18-02-02: If the site was originally identified as, "...gas meter, } \\
\text { regulator, and plumbing..", the 'after' photograph reveals that, at } \\
\text { least, the plumbing is still present. Therefore, this site is not ready } \\
\text { for closure. }\end{array}$ & $\begin{array}{l}\text { The site was originally identified as "gas meter, regulator, and } \\
\text { plumbing possibly extending from an underground tank in } 17 \\
\text { Camp about } 85 \text { yards west of Gas Station." From this } \\
\text { commentary, it was believed that waste of concern was an } \\
\text { UST, as stated in the FFACO. Documentation exists which } \\
\text { states the site consisted of an AST that had been removed at } \\
\text { the time the site was originally identified. The waste of } \\
\text { concern for CAS } 18-02-02 \text { has been removed and the piping } \\
\text { was handled in accordance with existing procedures at the } \\
\text { time. }\end{array}$ & Yes \\
\hline $\begin{array}{l}\text { Comment } 6 \\
\text { Page } 16\end{array}$ & & $\begin{array}{l}\text { CAS 25-01-09: According to the May 14, } 1992 \text { REECo Detailed } \\
\text { Site Activity Summary, rad screening and sampling was } \\
\text { performed on the tank. Please provide this data. }\end{array}$ & $\begin{array}{l}\text { An extensive search has been conducted to locate any } \\
\text { information associated with this CAS but very little } \\
\text { documentation has been identified. The ITLV Library, EM } \\
\text { Library, BN Archives, and DOE/NV Central Files were } \\
\text { searched for pertinent documentation. Specific rad screening } \\
\text { and sampling information pertaining to this tank could not be } \\
\text { located. }\end{array}$ & Yes \\
\hline $\begin{array}{l}\text { Comment } 7 \\
\text { Page } 17\end{array}$ & & $\begin{array}{l}\text { CAS 25-01-11: According to the May 14, } 1992 \text { REECo Detailed } \\
\text { Site Activity Summary, rad screening and sampling was } \\
\text { performed on the tank. Please provide this data. }\end{array}$ & See the response to comment five. & Yes \\
\hline $\begin{array}{l}\text { Comment } 8 \\
\text { Page } 18\end{array}$ & & $\begin{array}{l}\text { CAS 25-01-14: According to the May 14, } 1992 \text { REECo Detailed } \\
\text { Site Activity Summary, rad screening and sampling was } \\
\text { performed on the tank. Please provide this data. }\end{array}$ & See the response to comment five. & Yes \\
\hline $\begin{array}{l}\text { Comment } 9 \\
\text { Page } 19\end{array}$ & & $\begin{array}{l}\text { CAS 25-23-14: The interviewees indicated that the tank was } \\
\text { "...buried or emptied in a pit..below the portal...". The fact that the } \\
\text { tank is no longer present does not justify closure of the CAS. The } \\
\text { possibility of further investigation is an issue for this CAS. }\end{array}$ & See the response to comment one. & Yes \\
\hline $\begin{array}{l}\text { Comment } 10 \\
\text { Page } 20\end{array}$ & & $\begin{array}{l}\text { CAS 26-02-03: If this is not the current status of the CAS, please } \\
\text { provide a photograph revealing the current status of the CAS. }\end{array}$ & A photograph currently depicting the site has been provided. & Yes \\
\hline
\end{tabular}




\section{Distribution}

*Distribute only if Rev. 0 is approved without changes.

Copies

Paul J. Liebendorfer

State of Nevada

Bureau of Federal Facilities

Division of Environmental Protection

333 W. Nye Lane, Room 138

Carson City, NV 89706-0851

Michael McKinnon

State of Nevada

Bureau of Federal Facilities

Division of Environmental Protection

555 E. Washington, Suite 4300

Las Vegas, NV 89101

Sabrina Lawrence

Environmental Restoration Division

DOE/Nevada Operations Office

P.O. Box 98518, M/S 505

Las Vegas, NV 89193-8518

Janet Appenzeller-Wing

Environmental Restoration Division

DOE/Nevada Operations Office

P.O. Box 98518, M/S 505

Las Vegas, NV 89193-8518

Brad Jackson

IT Corporation

P.O. Box 93838

Las Vegas, NV 89193

Bob Bull

IT Corporation

P.O. Box 93838

Las Vegas, NV 89193
2 (Controlled)

1 (Controlled)

1 (Controlled)

2 (Uncontrolled)

1 (Uncontrolled)

1 (Uncontrolled) 
Bernadine Bailey

IT Corporation

P.O. Box 93838

Las Vegas, NV 89193

IT Corporation Central Files

P.O. Box 93838

Las Vegas, NV 89193

U.S Department of Energy

Nevada Operations Office

Technical Information Resource Center

P.O. Box 98518

Las Vegas, NV 89193-8518

U.S. Department of Energy

Nevada Operations Office

Public Reading Facility

P.O. Box 98521

Las Vegas, NV 89193-8521

U.S. Department of Energy

Office of Scientific and Technical Information

P.O. Box 62

Oak Ridge, TN 37831-0062

FFACO Group

IT Corporation

P.O. Box 93838

Las Vegas, NV 89193
1 (Uncontrolled)

1 (Uncontrolled)

1 (Uncontrolled)*

1 (Controlled)*

1 (Uncontrolled)*

1 (Uncontrolled, electronic copy)*

1 (Controlled)*

1 (Uncontrolled)* 